MARA MARIA IZAR DE MAIO GODOI

\title{
PHYTOMONAS E OUTROS TRIPANOSSOMATÍDEOS EM INSETOS NO ESTADO DE RONDÔNIA \\ - Amazônia Ocidental -
}

Dissertação apresentada ao Instituto de Ciências Biomédicas da Universidade de São Paulo, para obtenção do título de Mestre em Ciências. 
MARA MARIA IZAR DE MAIO GODOI

\section{PHYTOMONAS E OUTROS TRIPANOSSOMATÍDEOS EM INSETOS NO ESTADO DE RONDÔNIA \\ - Amazônia Ocidental -}

Dissertação apresentada ao Instituto de Ciências Biomédicas da Universidade de São Paulo, para obtenção do título de Mestre em Ciências.

Área de Concentração:

Biologia da Relação Patógeno-Hospedeiro.

Orientador:

Prof. Dr. Erney F. Plessmann de Camargo. 


\section{SÃO PAULO \\ 2000}

\section{DADOS DE CATALOGAÇÃO NA PUBLICAÇÃO (CIP)}

Serviço de Biblioteca e Informação Biomédica do

Instituto de Ciências Biomédicas da Universidade de São Paulo

Godoi, Mara Maria Izar de Maio.

Phytomonas e outros Tripanossomatídeos em insetos no estado de Rondônia Amazônia ocidental / Mara Maria Izar de Maio Godoi. -- São Paulo, 2000.

Dissertação (Mestrado) -- Instituto de Ciências Biomédicas da Universidade de São

Paulo. Departamento de Parasitologia.

Área de concentração: Biologia da Relação Patógeno-Hospedeiro.

Linha de pesquisa: Parasitologia.

Orientador: Camargo, Erney Felício Plessman de.

Versão do título para o inglês: Phytomonas and others Trypanosomatids of Insects in

Rondônia States. -Occidental Amazon-

Descritores: 1. Tripanossomatídeos em insetos

2. Diagnóstico 3. SL-PCR 4 . Hibridação 5. "Spliced leader" 6. Amazônia Ocidental 
Candidata: Mara Maria Izar de Maio Godoi.

Título da Dissertação: Phytomonas e outros Tripanossomatídeos em insetos no estado de Rondônia - Amazônia Ocidental.

A Comissão Julgadora dos trabalhos de Defesa da Dissertação de Mestrado, em sessão pública realizada a ............................... considerou o(a) candidato(a):
( ) Aprovada
( ) Reprovada

1) Examinador(a)

2) Examinador(a)

3) Presidente 
Este trabalho contou com apoio financeiro do PRONEX e com bolsa de estudos da CAPES/CNPq. 
Ao meu marido

Sem seu carinho, dedicação, amor e respeito, com seu apoio ilimitado, sempre meu porto seguro ...nada seria construído. 
Aos meus filhos

Jose Roberto,

Guilherme e

Rafael,

Que souberam valorizar e estimular as conquistas realizadas. 


\section{AGRADECIMENTOS}

Ao professor Dr Erney F. Plessmann de Camargo pela valiosa orientação, pela oportunidade que me foi concedida e pela confiança em mim depositada.

Ao professor Dr Luis Hildebrando Pereira da Silva por ter me trazido de volta à pesquisa e pelo muito que me auxiliou na fase inicial da execução do projeto.

Aos professores do Departamento de Ciências Biomédicas da Universidade Federal de Rondônia que com seu trabalho sustentaram minha ausência.

A professora $\mathrm{Dr}^{\mathrm{a}}$ Marta M. G. Teixeira pelas sugestões apresentadas durante a realização deste trabalho.

Ao Professor Dr Osvaldo Marinoti pela oportunidade de realizar parte deste trabalho em seu laboratório.

A Ms Marta Campaner pela amizade e pela grande colaboração desde o início deste trabalho.

A Dr ${ }^{a}$ Rosa Amélia Maldonado pela amizade e sugestões precisas no momento certo.

Ao Professor Dr Gehrard Wunderlich pelo incentivo e colaboração em todos os momentos.

Aos professores do Departamento de Parasitologia do ICB/USP e do CEPEM que contribuíram para minha formação.

A amiga Maria José Menezes pela insubstituível amizade e colaboração em todos os momentos. 
Ao Wolfgang Fisher pela amizade e pela manutenção técnica do laboratório.

A Dra Mirna Serrano pelo auxílio e sugestões na realização deste trabalho.

Aos amigos e colegas de trabalho do CEPEM, Centro de Pesquisa de Malaria do estado de Rondônia pelo agradável convívio.

A Wilma, Yladir e Cidinha, secretárias da pós-graduação do Departamento de Parasitologia pela amizade e pelo auxílio nos assuntos burocráticos.

Ao Cassiano pela ajuda na parte de informática.

Aos meus familiares que sempre tiveram palavras de incentivo e várias atitudes de apoio.

A todos os amigos do Departamento de Parasitologia, Lis, Fabiana, Renata, Renata Kelly, Flávia, Fernando, Erica, Claudia, Leila, Cris, Andréia, Enios e outros pelo ambiente agradável de convívio ajudando a segurar a saudades.

A todos que direta ou indiretamente contribuíram para a realização deste trabalho 
Sumário 
Lista de figuras I

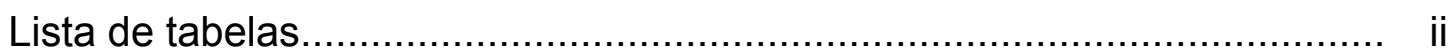

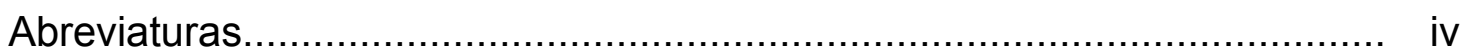

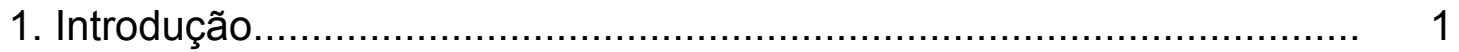

1.1. A Família Trypanosomatidae........................................................... 2

1.2. O Gênero Phytomonas..............................................................

1.2.1.Mofologia ........................................................................... 5

1.3. Tripanossomatídeos de insetos........................................................ 7

1.3.1 Tripanossomatídeos de emípteros................................................. 7

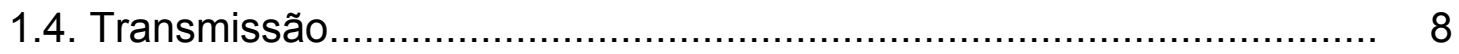

1.5. Identificação e taxonomia......................................................... 10

1.5.1. Características moleculares..................................................... 11

1.5.1.1. Mecanismos de trans-splicing................................................... 12

1.5.1.2. Trans-splicing em Phytomonas................................................... 13

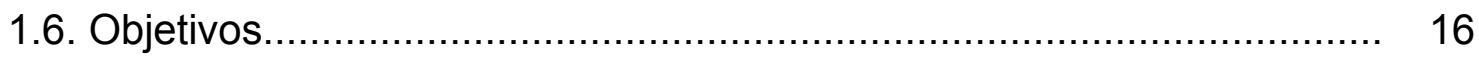

2. Materiais e Métodos................................................................... 18

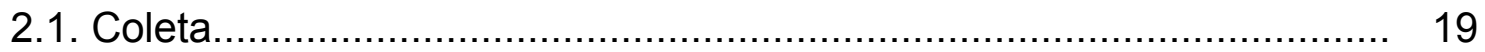

2.2. Isolamento, cultura e manutenção................................................... 20

2.3. Morfologia e Morfometria............................................................ 22

2.4. Extração do DNA ......................................................................... 23

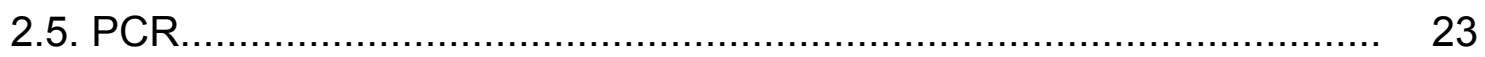

2.6. Transferência de DNA ............................................................. 24

2.7. Fosforilação do oligonucleotídeo.................................................... 25

2.8 Reações de hibridização, lavagem e processamento das membranas.. 25

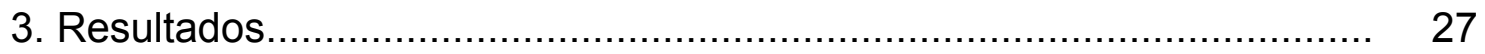

3.1 Levantamento e identificação das espécies de insetos hemípteros.... 28

3.2 Distribuição de hemípteros fitófagos nas estações climáticas................ 28 
3.3Tripanossomatídeos isolados de hemípteros..................................... 30

3.4 Morfologia e Morfometria....................................................... 30

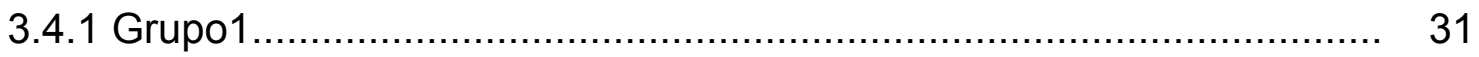

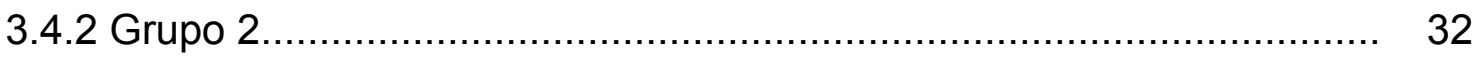

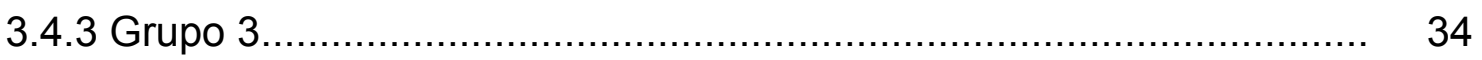

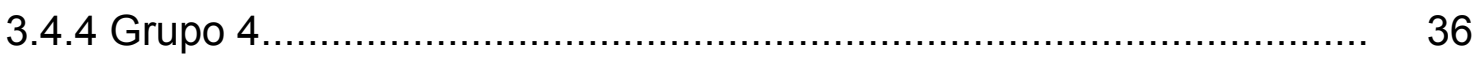

3.5 Marcadores Moleculares............................................................. 37

3.5.1Comparação do grupo Phytomonas com grupos 1, 2, 3 e $4 \ldots \ldots \ldots \ldots \ldots . . . . \quad 41$

3.5.2 Análise dos resultados utilizando marcadores moleculares............... 43

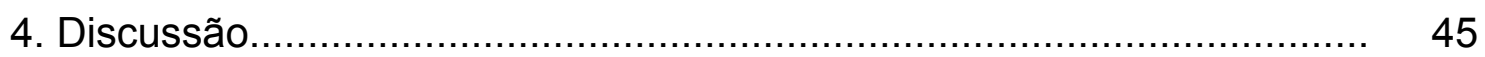

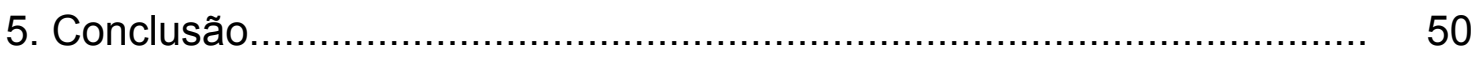

6. Referências Bibliográficas........................................................... 53

Resumo

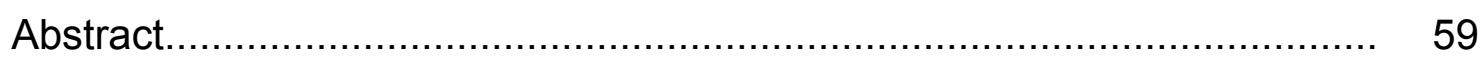

Esta dissertação contém um CD 


\section{Lista de Figuras}

Figura $n^{\circ}$ página

1- Estágios morfológicos de tripanossomatídeos inferiores....... 2

2- Flagelados encontrados no látex de Euphorbia.................. 5

3- Exemplos de polimorfismo e plasticidade........................ 6

4- Ciclo de vida dos Phytomonas.................................... 9

5- Representação esquemática da via de spliced-leader.......... 12

6- Representação esquemática do gene SL de Phytomonas.... 13

7- Oligonucleotídeos PSL1, PSL2, sonda SL3..................... 24

8- Representativo de amplificação e hibridação ...................... 37 


\section{Lista de Tabelas}

Tabela $\mathrm{n}^{0}$

1- Hemípteros coletados em Rondônia.

2- Hemípteros coletados em Rondônia nas duas estações climáticas.

3- Prevalência de tripanossomatídeos, segundo gênero e espécie de hemípteros.

4- Cultura de tripanossomatídeos.

5- Tripanossomatídeos do Grupo 1.

6- Medidas em $\mu \mathrm{m}$ dos tripanossomatídeos do Grupo1.

7- Tripanossomatídeos do grupo 2

8- Medidas em $\mu \mathrm{m}$ dos tripanossomatídeos do Grupo 2.

9- Tripanossomatídeos do grupo 3.

10- Medidas em $\mu \mathrm{m}$ dos tripanossomatídeos do Grupo $3 .$.

11- Tripanossomatídeos do grupo 4.

12- Medidas em $\mu \mathrm{m}$ dos tripanossomatídeos do Grupo 4.

13- Detecção de Phytomonas de hemípteros infectados com tripanossomatídeos a partir do DNA amplificado de glândulas salivares e tubo digestivo por Try-SLPCR e hibridação com a sonda SL3'....

14- Detecção de Phytomonas utilizando como molde o DNA de glândulas salivares e tubo digestivo de hemípteros extraídos de laminas negativas para MI para amplificação por Try-SLPCR e hibridação com SL3'.

15- Amplificação por Try-SLPCR do DNA de tripanossomatídeos extraídos de laminas e hibridação com a sonda SL3'....

16- Amplificação por Try-SLPCR e hibridação com SL3' de DNA de tripanossomatídeos extraídos de lâminas, das formas coanomastigotas e amastigotas. 
17- Amplificação por Try-SLPCR e hibridação com SL3' de DNA de tripanossomatídeos extraídos de lâminas, positivos para MI.......... 40

18- Amplificação por Try-SLPCR e hibridação com SL3' de DNA de tripanossomatídeos extraídos de lâminas.....

19- Relação Phytomonas identificadas por marcadores moleculares... 42

20- Medidas em $\mu \mathrm{m}$ de Phytomonas sp........................................... 43

21- Relação de Trypanosomatidae e Phytomonas definidos por marcadores moleculares e espécies de hemípteros. 


\section{Abreviaturas}

ACMs

dATP

DNA

IM

LIT

mRNA

nt

PBS

pb

PCR

Phy-SLPCR

pre-mRNA

pre-medRNA

RNA

SDS

SL

SLPCR

SL3'

SSC

TCC-USP

Try-SLPCR anticorpos monoclonais

desoxiadenosinatriposfato

acido desoxirribonucléico

investigação microscópica

Liver Infusion Triptose

RNA mensageiro

nucleotídeos

Phosphate buffered salilne

(salina tamponada com fosfato)

pares de bases

Polimerase Chain Reaction

(reação em cadeia da Polimerase)

PCR para amplificação de DNA de Phytomonas

precursor do RNA mensageiro.

precursor do pre-mRNA

acido ribonucléico

dodecil sulfato de sódio

"spliced lider"

"spliced lider" PCR

sonda específica para gênero Phytomonas.

solução citrato salina padrão

Trypanosomatid Culture Collection of the University of São Paulo

PCR para amplificação Trypanosomatidae 
1. INTRODUÇÃO 


\subsection{A Família Trypanosomatidae}

A ordem Kinetoplastida compreende organismos flagelados com um ou dois flagelos e uma única mitocôndria organizada em torno de uma rede de fibrilas concatenadas de DNA que em conjunto constituem o cinetoplasto, localizado à base do flagelo.

A família Trypanosomatidae compreende Kinetoplastida com um único flagelo. São todos parasitas mono ou heteroxênicos.

Os gêneros Trypanosoma, Leishmania, Endotrypanum e Phytomonas são parasitas heteroxênicos com hospedeiros invertebrados e vertebrados ou plantas no caso de Phytomonas. Outros quatro gêneros, Blastocrithidia, Crithidia, Leptomonas e Herpetomonas são parasitas monoxênicos de insetos e de outros poucos invertebrados. A localização do cinetoplasto em relação ao núcleo, a presença ou ausência de membrana ondulante e flagelo são as principais características que definem morfologicamente as diversas formas evolutivas dos tripanossomatídeos (Wallace, 1966) (fig.1).

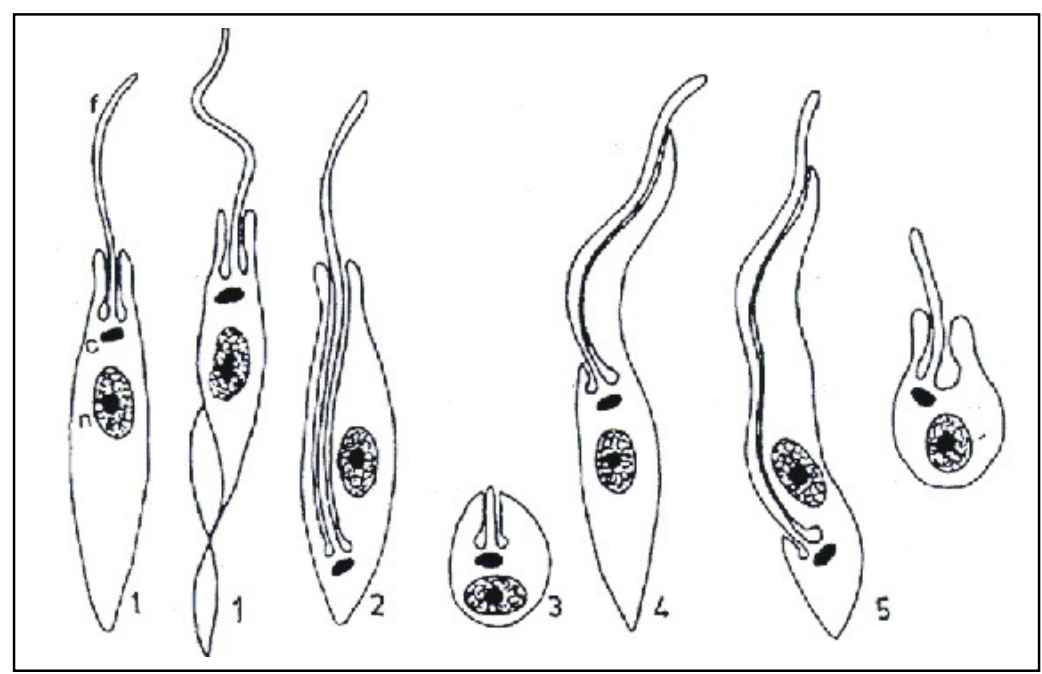

Fig. 1 - Estágios morfológicos de tripanossomatídeos inferiores 1 - promastigota, 2 opistomastigota, 3 - amastigota, 4 - epimastigota, 5 - tripomastigota, 6 -coanomastigota (apud Vickerman, 1976). 
No gênero Leptomonas, encontramos tripanossomatídeos monogenéticos, parasitas de protozoários e metazoários como nematódeos, moluscos e uma ampla variedade de insetos como dípteros, hemípteros, himenópteros, sifonápteros e anopluros onde são encontrados no trato digestivo, hemocele e nas glândulas salivares. Em seu ciclo evolutivo aparecem formas promastigotas, acompanhadas ou não de cistos (Wallace, 1966).

No gênero Herpetomonas, encontramos parasitas monogenéticos do trato digestivo de insetos, principalmente dípteros, embora tenham sido descritos também em outros insetos, inclusive hemípteros e lepidópteros. Apresentam em seu ciclo evolutivo as formas promastigotas e opstomastigotas sendo que a forma opistomastigota caracteriza o gênero (Wallace, 1966).

No gênero Crithidia encontramos parasitas que têm a extremidade anterior truncada em funil ou colar, tomando um aspecto de "grão de cevada". O flagelo apresenta movimento circular diferente dos demais tripanossomatídeos (Wallace, 1966).

O gênero Blastocrithidia, de hemípteros, tem a morfologia característica dos epimastigota, com uma membrana ondulante que acompanha o flagelo antes de sua emergência do corpo celular. O gênero é de fácil reconhecimento tanto em preparações a fresco como coradas, porém de difícil isolamento e cultivo em laboratório (Wallace, 1966).

São incluídos no gênero Leishmania flagelados heteroxênicos, parasitas de insetos flebotomíneos, nos quais são encontradas formas promastigotas, e de vertebrados, onde proliferam sob a forma de amastigotas intracelulares de macrófagos.

O gênero Trypanosoma é constituído de parasitas heteroxênicos de triatomíneos e de vertebrados, em cujo ciclo se alternam formas epimastigotas e 
tripomastigotas (nos insetos); amastigotas intracelulares e tripomastigotas (nos vertebrados).

O gênero Endotrypanum é representado por parasitas heteroxênicos de flebotomíneos e mamíferos. Formas promastigotas e amastigotas são encontradas nos insetos, enquanto nos mamíferos, ocorrem as formas epimastigota e tripomastigota intra-eritrocitárias.

O gênero Phytomonas ocorre em plantas sob a forma de longos promastigotas com torções ao longo do corpo. Nos insetos eles também ocorrem como promastigotas, mas sem o que os distinga dos promastigotas de outros gêneros de tripanossomatídeos. (Camargo, 1999).

\subsection{O Gênero Phytomonas.}

Lafont deu o nome de Leptomonas davidi a flagelados encontrados no látex de Euphorbia pilulifera. No mesmo ano, 1909, Donovan propôs o nome de Phytomonas como nome genérico para tripanossomatídeos parasitas de plantas, mas essa terminologia não foi aceita e durante muitos anos os flagelados de plantas eram referidos ao gênero Leptomonas ou Herpetomonas. Foi somente entre 1970 e 1980 que a denominação Phytomonas ganhou maior aceitação como nome genérico. Embora, como se demonstrou mais tarde, nem todos os flagelados de plantas fossem Phytomonas (Camargo, 1999).

Os Phytomonas são parasitas comumente encontrados no látex, floema, suco de frutas, sementes, albúmem, e néctar de muitas famílias de plantas. Eles são inoculados em seus hospedeiros com a saliva de insetos hemípteros fitófagos. Há controvérsias sobre a patogenicidade deste gênero em plantas laticíferas ou frutas, porém é certo que os parasitas do floema são patogênicos em coqueiros, dendezeiros, e que podem causar epidemias letais em mandioca e café, epidemias estas responsáveis pela destruição de muitas plantações na América Central e do Sul (Camargo, 1999). 


\subsubsection{Morfologia}

A maioria dos flagelados de plantas apresenta-se como promastigotas segundo a terminologia de Hoare \& Wallace (1966).

Morfologicamente não é possível distinguir tripanossomatídeos de plantas de tripanossomatídeos de insetos. Talvez seja por essa razão que os dois grupos constituíssem juntos o chamado grupo dos tripanossomatídeos inferiores, uma denominação que está aparentemente em desacordo com sua posição filogenética.

A microscopia óptica revela uma estrutura em comum para esse tipo de Trypanosomatidae: um núcleo, um cinetoplasto, um corpo celular alongado e um flagelo. O corpo celular torcido ao longo de um eixo longitudinal é uma característica comum adicional, porém não privativa dos promastigotas do gênero Phytomonas.

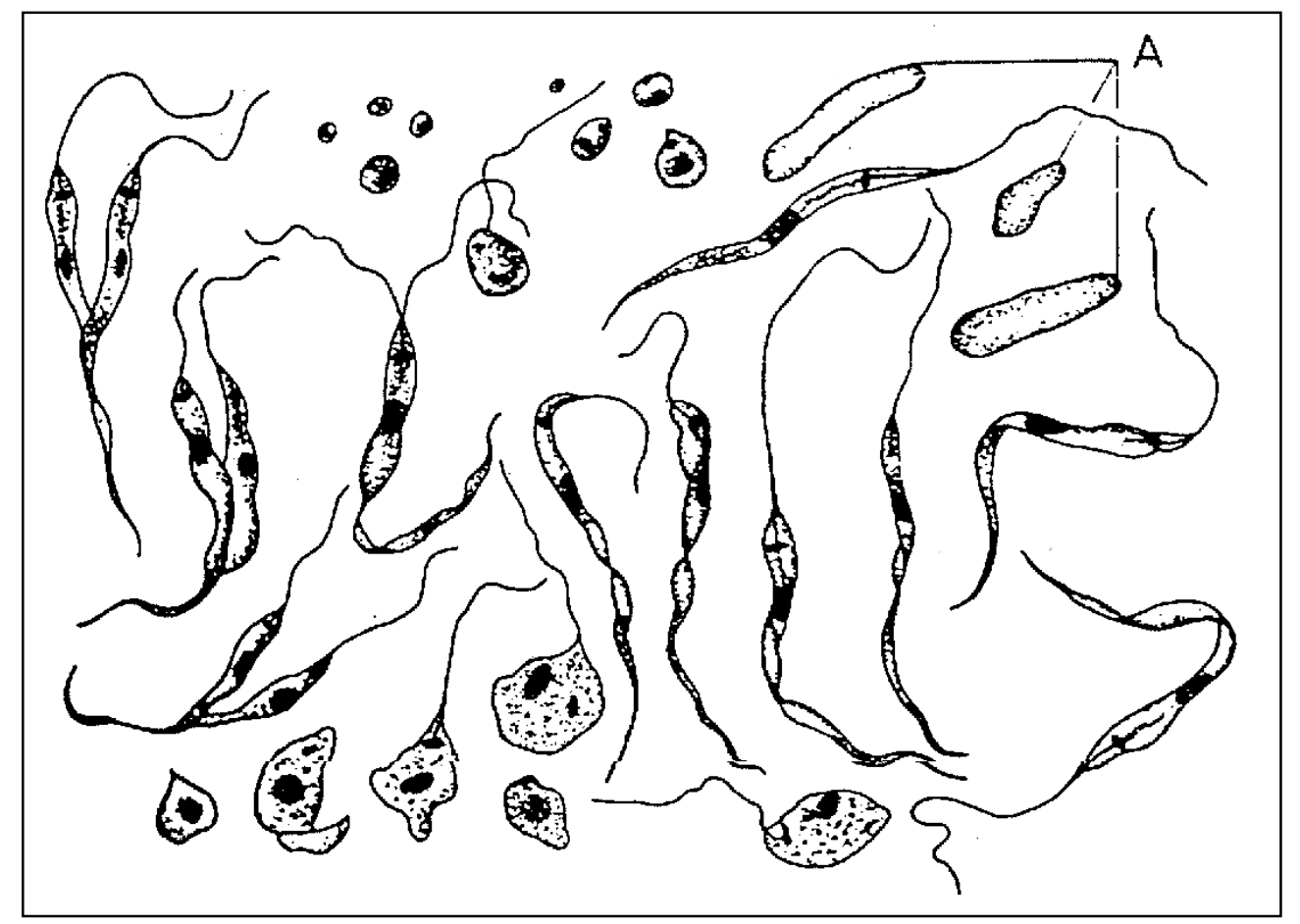

Fig. 2 - Flagelados encontrados no látex de Euphorbia. 'A' corresponde a grânulos de amido (apud Lafont, 1910). 
Como os tripanossomatídeos de insetos, os flagelados de plantas se multiplicam por divisão binária longitudinal. Apesar de se reproduzirem por fissão binária e de possuírem morfologia promastigota, os flagelados de plantas apresentam extremo polimorfismo. Uma mesma espécie pode apresentar diferentes formas e tamanhos, não somente em diferentes hospedeiros ou meios de cultura como também no mesmo hospedeiro (França, 1920) (fig. 2).

O polimorfismo dos flagelados de plantas ocorre também em seus hospedeiros intermediários. Jankevicius et al. (1989) descreveram promastigotas com grande polimorfismo quanto ao comprimento do corpo celular, no intestino (4,1 a 16,6 $\mu \mathrm{m})$, nos túbulos de Malpighi $(5,6 \mu \mathrm{m})$ e nas glândulas salivares $(5,7 ; 24$ e $80 \mu \mathrm{m}$ ) de Phthia picta, inseto vetor de Phytomonas serpens (Fig. 3).

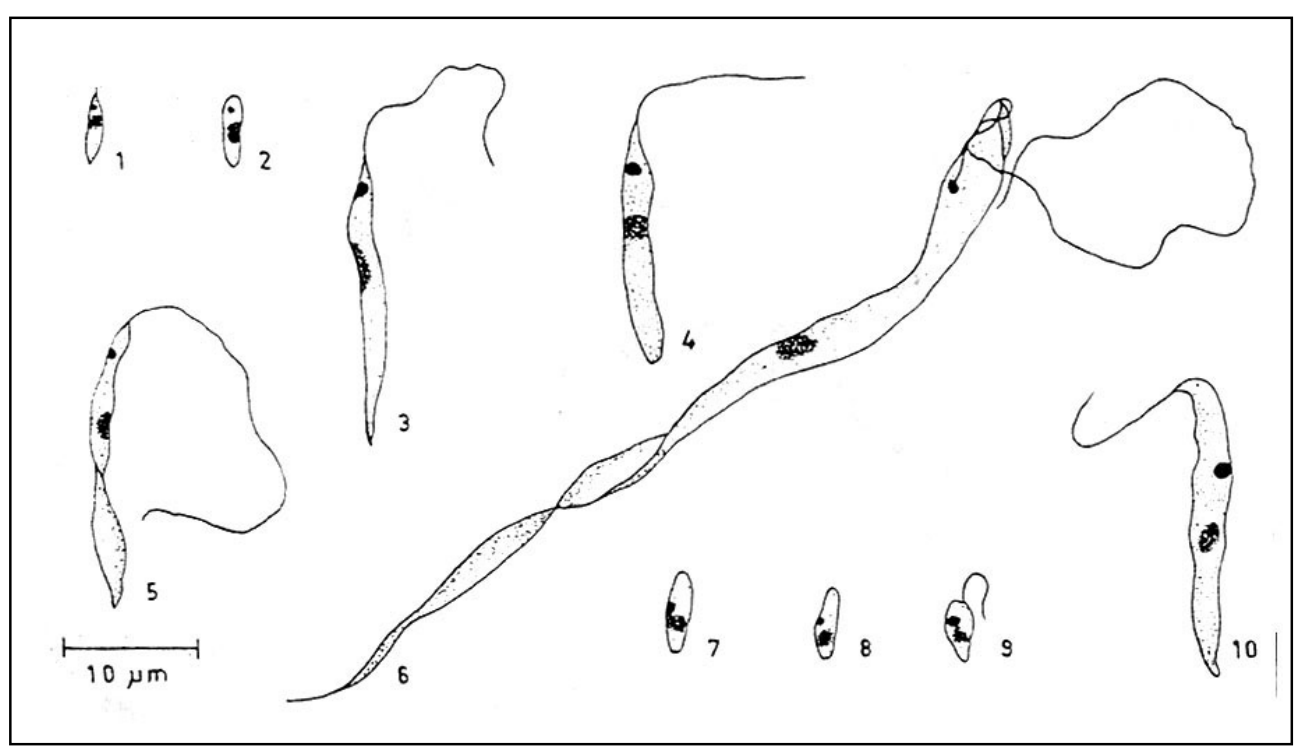

Fig. 3 - Exemplos de polimorfismo e plasticidade morfológica em flagelados de plantas são numerosos. Alguns podem ser artefatos resultantes de $\mathrm{pH}$ alterado ou, de mudanças osmóticas ou nutricionais entre outras. (apud Jankevicius et al. 1989).

Os promastigotas também podem apresentar polimorfismo em um mesmo meio de cultura. Jankevicius et al. (1989) mostraram que promastigotas pequenos $(10 \mu \mathrm{m})$, sem torções ao longo do corpo, predominavam em culturas em meio LIT (Liver Infusion Tryptose medium); com o envelhecimento das culturas apareciam gigantes promastigotas de $60 \mu \mathrm{m}$, com torções ao longo do corpo.

Camargo em revisão de 1999 considera que o polimorfismo dos flagelados de plantas tem duas importantes implicações: 
1 - Promastigotas morfologicamente distintos podem corresponder a um estágio ainda desconhecido de desenvolvimento do ciclo de vida destes flagelados. Em cada tipo de hospedeiro (planta ou inseto) o flagelado muda sua forma e, presumivelmente, sua fisiologia. Estas mudanças podem ser seqüencialmente programadas e podem corresponder a etapas do ciclo biológico, como nos outros dois gêneros heteroxênicos Trypanosoma e Leishmania. 2 - O marcante polimorfismo intra-específico dos flagelados de plantas inviabiliza a morfologia como parâmetro identificatório e/ou taxonômico. Isto porque promastigotas de uma determinada espécie podem assemelhar-se mais a formas evolutivas de outras espécies. Medidas do comprimento do corpo e do flagelo tanto quanto à distância do núcleo para o cinetoplasto (que eram considerados critérios taxonômicos no passado) são hoje considerados inadequados para tal finalidade.

\subsection{Tripanossomatídeos de insetos}

Uma das primeiras observações de tripanossomatídeos em insetos foi feita por Antony van Leeuwenhoek, no trato digestivo de tabanídeos em 1632. A partir daí muitas espécies de tripanossomatídeos foram encontradas em muitas das famílias de artrópodes.

Atualmente são conhecidas aproximadamente 850.000 espécies de insetos. Destas, 348 espécies foram encontradas parasitadas por tripanossomatídeos (Wallace, 1983).

\subsubsection{Tripanossomatídeos em Hemípteros}

Aders, em 1909, foi o primeiro a relatar em trato digestivo e glândulas salivares de um hemíptero fitófago, Aspongopi viduatus, a presença de numerosos flagelados de diferentes formas e tamanho que foram classificados como Herpetomonas aspongopi. 
Hemípteros fitófagos abrigam muitas espécies de tripanossomatídeos hetero e monoxênicos. Dados da literatura descrevem cerca de 100 diferentes espécies de flagelados encontrados em diferentes espécies de plantas onde se alimentam os hemípteros (Camargo \& Wallace, 1994). Se considerarmos que são 23000 espécies conhecidas na Ordem dos Hemípteros, fica evidente que somente uma pequena fração de parasitas e hospedeiros é conhecida até agora.

Dos hemípteros encontrados parasitados por flagelados, $9 \%$ eram da família Lygaeidae, $40 \%$ da família Coreidae, 44\% da família Pyrrhocoridae e 18\% da família Pentatomidae (Sbravate et al., 1989). A prevalência geral de flagelados em Hemípteros fitófagos foi de $35 \%$. Os tripanossomatídeos foram encontrados no tubo digestivo, hemocele e glândulas salivares dos insetos hospedeiros. Dentre os insetos infectados, $68,4 \%$ tinham flagelados exclusivamente no trato digestivo, outros $31,6 \%$ tinham flagelados em suas glândulas salivares e $31,6 \%$ apresentavam infecção do trato digestivo e das glândulas salivares. Dentre os protozoários encontrados a grande maioria era representada por promastigotas $(99,9 \%)$ com grandes torções ao longo do corpo e uns poucos epimastigotas e coanomastigotas, geralmente misturados com os promastigotas.

Os flagelados encontrados em hemípteros fitófagos não são necessariamente parasitas de plantas. Eles podem ser parasitas monoxênicos de insetos. Os epimastigotas e coanomastigotas foram identificados como Blastocrithia e Crithidia, respectivamente, mas os promastigotas deixam sempre dúvida se são Leptomonas, Phytomonas ou Herpetomonas (Camargo, 1999).

\subsection{Transmissão}

Camargo \& Wallace (1994) reviram as observações e experimentações sobre a transmissão de flagelados de plantas e descreveram as várias evidências que ligam hemípteros fitófagos à transmissão de Phytomonas para plantas. Lafont encontrou o Lygaeidae, Nysius euphorbiae, em plantas que abrigavam Leptomonas davidi tendo obtido infecção experimental de plantas com insetos alimentados em plantas naturalmente infectadas Da mesma maneira vários 
autores: Bouet \& Roubaud, Strong, Holmes, Vickerman, McGhee, Hanson e outros também apresentaram evidências sobre o papel dos hemípteros na transmissão de flagelados de plantas (Camargo \& Wallace, 1994).

Vale ressaltar a experiência de Jankevicius et al. (1989) na transmissão de Phytomonas serpens de Phthia picta, criados em laboratório, para tomates cultivados em laboratório (fig 4).

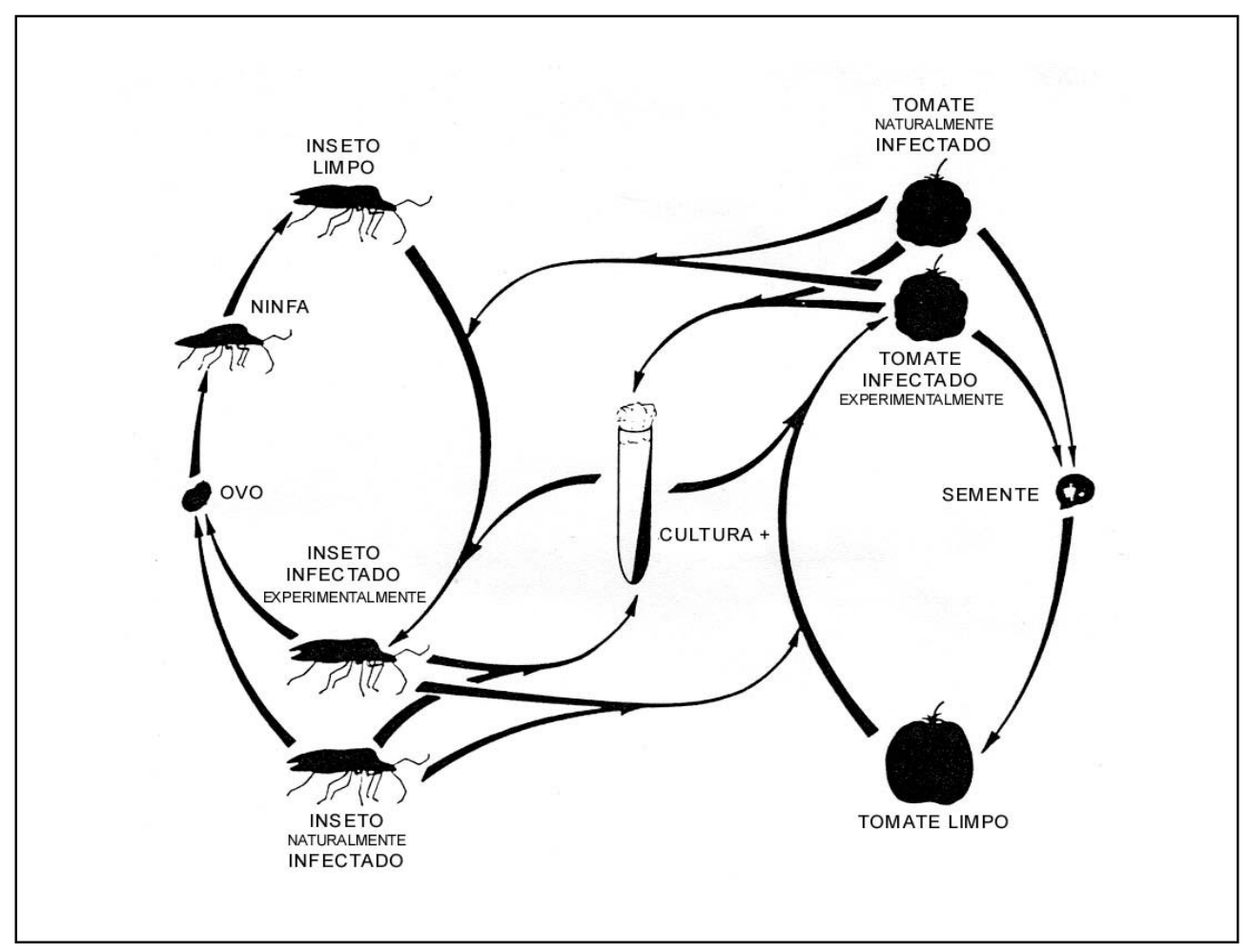

Fig. 4 - Experimentos sobre o ciclo de vida de Phytomonas serpens envolvendo tomates/insetos/cultura. (Jankevicius et al., 1989).

Infecções experimentais de frutos de solanáceas também foram realizadas por Kastelein \& Camargo (1990) que conseguiram infectar insetos a partir de frutos infectados e infectar frutos, inclusive tomates, a partir de pentatomídeos infectados. 


\subsection{Identificação e Taxonomia}

A taxonomia dos tripanossomatídeos de insetos permaneceu confusa até que Wallace propôs características morfo-evolutivas para definir os gêneros da família Trypanosomatidae (Wallace, 1966). Mesmo com esses novos critérios, a posição taxonômica do gênero Phytomonas continuou confusa, pois o critério hospedeiro de origem (plantas) continuava balisando sua definição (Camargo, 1999).

As características morfológicas e o hospedeiro de origem que constituíam os parâmetros básicos para identificação do gênero e descrição de espécies de tripanossomatídeos, revelaram-se com o tempo insuficientes para os tripanossomatídeos inferiores (Camargo et al., 1990).

O critério morfológico é inadequado visto que estágios morfológicos idênticos são compartilhados por vários gêneros em alguma fase do ciclo. As formas promastigotas podem ocorrer nos gêneros Leptomonas, Herpetomonas, Phytomonas, Leishmania e Endotrypanum. Nessas circunstâncias a descrição morfológica simples, sem critérios adicionais, não pode esclarecer a posição taxonômica e classificação de um organismo sob estudo. Por outro lado, o critério hospedeiro de origem ficou abalado quando descrições de infecções mistas e resultados de infecções experimentais de insetos demonstraram que a suposta especificidade parasita-hospedeiro era irreal. Insetos de variadas espécies podiam hospedar espécies distintas de tripanossomatídeos enquanto estes eram capazes de infectar extensa variedade de insetos (Camargo, 1999).

Entre os Phytomonas, os critérios morfológico e hospedeiro de origem claramente provocavam conflito, principalmente quando pesquisadores isolaram de plantas, tripanossomatídeos que tinham características de outros gêneros de tripanossomatídeos (Conchon et al., 1989).

Sem muita escolha, pesquisadores iniciaram estudos comparativos que pudessem eventualmente mostrar uma característica comum entre 
tripanossomatídeos de plantas capaz de distingüi-los dos gêneros Leptomonas, Herpetomonas e Crithidia.

Quando Dollet obteve as primeiras culturas de flagelados de látex, as características bioquímicas, sorológicas e moleculares dos isolados de plantas passaram a ser investigadas (Dollet et al., 1982). Os primeiros estudos permitiram comparações entre tripanossomatídeos inferiores: determinação de requerimentos nutricionais (Silva \& Roitman, 1989), análise comparativa do padrão de migração eletroforética de isoenzimas (Camargo et al, 1982), análise do padrão radioautográfico de proteínas de superfície marcadas por iodo radioativo (Camargo et al., 1982), análise do padrão de migração eletroforética dos fragmentos de kDNA gerados por enzima de restrição (Camargo et al., 1982), estudo comparativo entre enzimas do ciclo ornitina arginina (Camargo et al., 1987), reatividade com anticorpos monoclonais específicos (Teixeira et al., 1989), testes de aglutinação com Lectinas (Petry et al., 1987), análise de restrição dos genes ribossomais dos tripanossomatídeos (Camargo et al., 1992) e sondagem do gene "spliced leader" (Nunes et al., 1995; Teixeira et al.,1996).

Esses métodos permitiram avançar na caracterização do gênero Phytomonas levando diversos autores a usá-los para a identificação de Phytomonas entre os tripanossomatídeos encontrados em insetos (Sbravate et al., 1989; Teixeira et al., 1996).

\subsection{1 - Características Moleculares: A análise de seqüências de DNA na caracterização de Tripanossomatídeos.}

Técnicas da Biologia Molecular têm sido utilizadas com êxito na identificação de parasitas, particularmente as reações de amplificação em cadeia (PCR - Polymerase Chain Reaction) acopladas a hibridizações com sondas específicas. (Nunes et al., 1995; Teixeira et al., 1996; Serrano et al., 1999).

Em Phytomonas, 2 conjuntos de genes têm recebido atenção por sua utilidade taxonômica, o DNA ribossomal e o gene "spliced leader" ou mini-exon. 
Aplicadas na identificação de parasitas cultivados em laboratório ou presentes em amostras biológicas de hospedeiros e vetores, seqüências específicas desses genes têm se revelado de grande utilidade diagnóstica (Teixeira et al., 1996; Serrano et al., 1999, a, b) e taxonômica (Serrano et al., 1999 c).

\subsubsection{Mecanismos de trans-splicing.}

O gene "spliced leader", SL, dos Kinetoplastida está envolvido no processo de maturação do RNA mensageiro, através de um mecanismo de trans-splicing restrito a protozoários, alguns nematódeos e platelmintos.

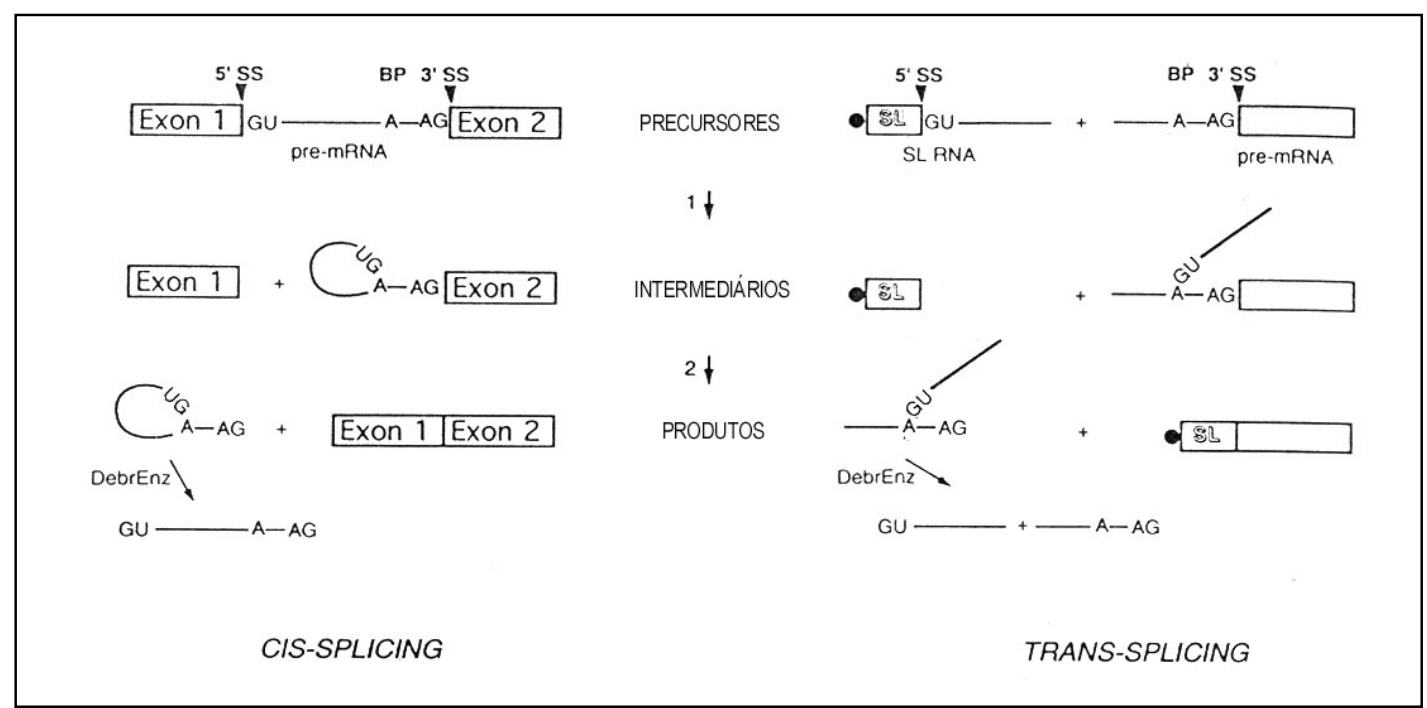

Fig.5 - Representação esquemática da via de spliced do pre-mRNA. Os exons estão nos boxes. . Bp, ponto de ramificação. DebrEnz, enzima de desramificação . O círculo representa a estrutura cap4 do SLRNA.

O trans-splicing é uma reação de processamento de RNA em que exons de duas moléculas distintas de RNA, o pre-mRNA e um pequeno RNA, o "spliced leader" (SL) RNA, são ligadas para formarem moléculas maduras de mRNA (fig 5). A seqüência SL que representa a extremidade 5' do SL RNA, é ligada ao sítio 3' de spliced localizado no limite do mRNA maduro dentro do pre-mRNA policistrônico (Agabian, 1990, Ullu, 1996). 


\subsubsection{Trans splicing em Phytomonas.}

Como para os tripanossomatídeos em geral, o processo de maturação do mRNA em Phytomonas também envolve o trans-splicing de uma seqüência de 39 nucleotídeos (nt) para um precursor, o pre-medRNA. Esse 39nt precursor é codificado pelo gene "spliced leader" ou mini exon encontrado no genoma de tripanossomatídeos entre 100-200 repetições em tandem (fig.6).

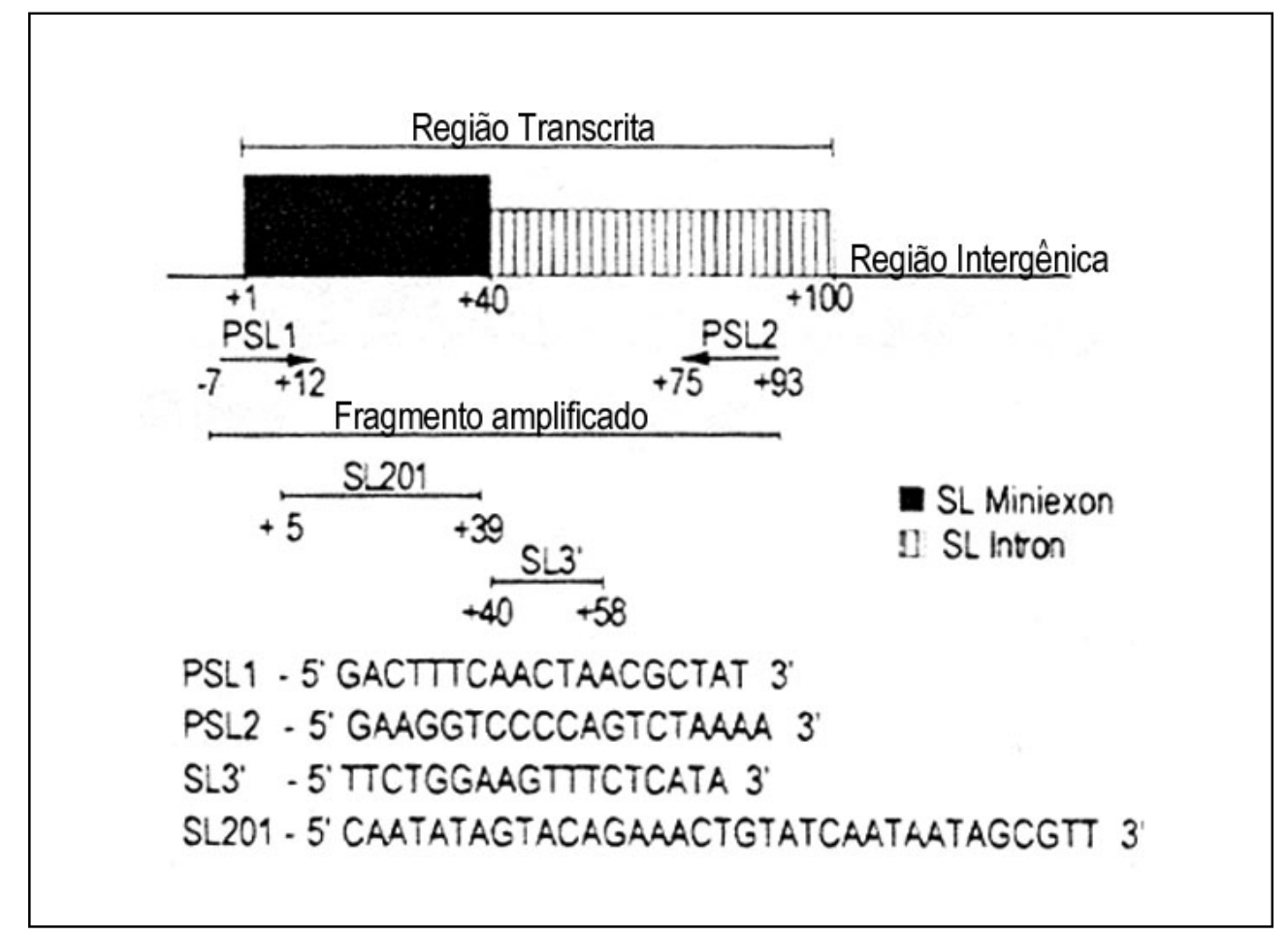

Fig. 6 - Representação esquemática do gene SL de Phytomonas sp.

Localização dos oligonucleotídeos PSL1 e PSL2, usados como iniciadores para amplificação por PCR, e os oligonucleotídeos SL3'e SL201, usados como sondas para hibridação por Southern blot.

Cada gene SL é formado de regiões transcritas e regiões não transcritas.

A região transcrita inclui um exon de 39nt que codifica o medRNA, seguido de um íntron de 50 a 110 pares de base $(\mathrm{pb})$.

A seqüência do exon é altamente conservada na família dos Trypanosomatidae com alguma variabilidade entre os gêneros, enquanto a região não transcrita mostra um alto grau de variabilidade entre os organismos (Nunes et al., 1995).

As seqüências do mini exon ou "spliced leader", foram determinadas por dois grupos diferentes Nunes et al., 1995 compararam a seqüência de 05 isolados 
de Phytomonas com as seqüências disponíveis de outros tripanossomatídeos e mostraram que a seqüência do íntron nas posições entre +40 e $+58 p b$ eram idênticas entre os isolados, mas diferiam das seqüências homólogas de outros tripanossomatídeos. Sturn et al., (1995), obtiveram resultados similares na comparação da seqüência do íntron SL de 03 isolados de Phytomonas de frutas, látex e floema.

Como observado em outros gêneros de tripanossomatídeos, os genes SL de Phytomonas exibem um alto grau ( $\geq 94 \%$ ) de seqüências homólogas em regiões transcritas. Regiões não transcritas demonstram ser bem menos conservadas (Nunes et al., 1995). Todos os isolados de Phytomonas são idênticos nos seus exons de 39nt e nos primeiros 19nt da seqüência do íntron.

As seqüências SL RNA dos isolados de Phytomonas podem ser usadas como identificadoras de gênero Phytomonas. Para explorar essa possibilidade Nunes et al., (1995) produziram a sonda SL3', complementar a região entre +40 e +58pb dos SL RNAs de todos os Phytomonas (fig 6). Essa seqüência é idêntica entre os isolados dos Phytomonas examinados, porém distintas de todos os outros gêneros de tripanossomatídeos.

Teixeira et al. (1996), testaram a hipótese da utilização do oligonucleotídeo SL3' como sonda gênero específica para 84 isolados de tripanossomatídeos. Os resultados da hibridação com a sonda SL3' coincidiram com os resultados de outros marcadores usados para identificar Phytomonas: a hibridação só foi positiva onde os flagelados eram IFA (imunoflorescência) positivo com os AcMs (anticorpos monoclonais) específicos para Phytomonas. Além disso, a hibridação positiva com o SL3' era sempre acompanhada da ausência de hibridação com o oligonucleotídeo SSU3, o que sugere ausência do sitio Pvull típica do gênero Phytomonas (Camargo et al., 1992).

Usando como iniciadores os oligonucleotídeos complementares às regiões flanqueadoras da seqüência SL3', Serrano et al., (1999), adaptaram a técnica do PCR para a identificação de Phytomonas em plantas e insetos 
fitófagos. Das seqüências alvo selecionadas como iniciadoras, uma, denominada PSL1, é muito conservada em todos os tripanossomatídeos, enquanto a outra, PSL2, é conservada em Phytomonas, incluindo os isolados de látex, frutas e floema, mas distinta de todas as seqüências de SL RNA de outros gêneros de tripanossomatídeos (Serrano et al., 1999a) (fig. 6).

As utilizações de condições de estringência diferentes no PCR permitiram seja a amplificação do DNA de todos os tripanossomatídeos (Try-SLPCR) seja a amplificação específica do DNA de Phytomonas (Phy-SLPCR), (Serrano et al., 1999a).

Com o objetivo de desenvolver um método de PCR para detecção de Phytomonas diretamente em plantas e possíveis insetos vetores, sem necessidade de cultura em grande escala, foram testados pelo método PhySLPCR preparações de diferentes tecidos de plantas bem como de glândulas salivares e tubo digestivo de insetos fitófagos (Serrano et al.,1999a).

Os resultados obtidos mostraram que esse método é totalmente apropriado para detecção de Phytomonas em diferentes espécies e famílias de insetos e plantas (Serrano et al.,1999a).

Contudo, tecidos de plantas e insetos recém coletados ou recém congelados não são os métodos usados rotineiramente para armazenar tripanossomatídeos. A maioria das coleções de tripanossomatídeos são guardadas como esfregaços fixados em lâminas de vidro. Assim para ampliar a utilização e aplicabilidade do método SLPCR, ele foi adaptado para trabalhar experimentalmente com o DNA de tripanossomatídeos recuperado de esfregaços fixados, corados, e armazenados até por vários anos (Teixeira et al., 2000).

Tripanossomatídeos, particularmente os do gênero Phytomonas, podem infectar frutos, seiva, látex de plantas de várias famílias vegetais e têm sido detectados em plantas e insetos fitófagos (seus possíveis transmissores) de várias regiões do velho e novo continente. 
Apesar da enorme variedade da flora e da fauna entomológica da Amazônia Brasileira, apenas 2 relatos existem sobre a ocorrência de tripanossomatídeos em plantas ou hemípteros fitófagos dessa região (Aragão, 1927, Sbravate et al., 1989).

A detecção de tripanossomatídeos em plantas e insetos pode ser feita por microscopia simples. Todavia a distinção entre Phytomonas e outros gêneros de tripanossomatídeos se constituía em um grande problema até recentemente, necessitando de isolamento e cultivo do flagelado e sua identificação por diferentes técnicas bioquímicas, sorológicas e moleculares. O processo diagnóstico era assim extremamente laborioso e problemático, o que praticamente impossibilitava a detecção de Phytomonas em plantas e insetos da Amazônia.

Com a adaptação do PCR para a detecção de Phytomonas em material fixado em lâminas, levantamentos da prevalência de tripanossomatídeos em especimens amazônicos tornou-se exeqüível, permitindo a obtenção dos dados constantes do presente trabalho.

\subsection{Objetivos}

Com o objetivo de estudar a prevalência de tripanossomatídeos e, particularmente de Phytomonas spp. em hemípteros fitófagos e plantas da região amazônica, nos propusemos inicialmente a:

1 - Coletar exemplares de insetos em diversos habitats da região de Porto Velho - Rondônia. Identificar ou providenciar a identificação dos exemplares coletados.

2 - Preparar esfregaços em lâmina do conteúdo do seu tubo digestivo terminal, corar e examinar por microscopía óptica esses esfregaços para determinação da presença de tripanossomatídeos;

3 - Documentar e registrar a morfologia e morfometria desses flagelados; 
4 - Extrair e amplificar por PCR o DNA das lâminas positivas para tripanossomatídeos;

5 - Hibridar os amplicons com a sonda SL3' para o diagnóstico do gênero Phytomonas, entre os tripanossomatídeos encontrados. 
2. Materiais e Métodos 


\subsection{Coleta}

Para a realização deste trabalho foram coletadas várias espécies de Insetos Hemípteros fitófagos no estado de Rondônia, estes organismos foram utilizados como fonte de tripanossomatídeos.

O estado de Rondônia limita-se ao norte com o estado do Amazonas a leste com o estado do Mato Grosso, ao sul com a República da Bolívia, e a oeste com o estado do Acre.

O clima predominante em Rondônia é o tropical úmido, com índice pluviométrico superior a $2000 \mathrm{~mm}$ anuais, e com pequenas variações de temperatura média anuais em torno de $26^{\circ} \mathrm{C}$, embora possa ocorrer o fenômeno da friagem (de maio a outubro), resultante das invasões da massa polar, provocando quedas na temperatura que chega a baixar para $10^{\circ} \mathrm{C}$. A estação chuvosa (o inverno regional) é longa e compreendida entre os meses de setembro a maio/junho. Registra-se, entretanto, um período de estiagem (junho a agosto) que, embora curto, reproduz o tipo de clima do Planalto Central (IBGE, 1995, 1996).

Hemípteros adultos foram coletados, no município de Porto Velho: nos km 11, 14, 16, 18, 36 da $\mathrm{Br}$ 364; na Universidade Federal de Rondônia; na praia do Tamanduá, na Cachoeira de Santo Antônio, na Cachoeira de Teotônio no Rio Madeira; na praia das Antas no rio Tapagem; no Parque Ecológico, no rio Maicí. No município de Triunfo, no município de Itapuã D'Oeste, e no município de Rolim de Moura.

Durante os meses de invernada (inverno regional) os insetos eram coletados após as chuvas e nos tempos de seca os insetos eram capturados pela manhã logo ao nascer do sol. Cada excursão contava com dois capturadores que trabalhavam por um período de duas horas de cada vez. Os hemípteros fitófagos eram capturados pelas patas com o auxílio de pinças ou com redes de filó e 
conservados em frascos de vidro ou plástico, cobertos com gaze presa por elástico. Nos frascos eram adicionadas folhas, flores ou frutos da planta de onde os hemípteros foram coletados e algodão umedecido com água para garantir sua sobrevivência. Nos frascos eram anotados o local da coleta e a data e, quando possível, a identificação da planta de origem.

As coletas foram feitas durante o período de março de 1988 a janeiro de 1999.

Foram coletados 244 hemípteros fitófagos. Dois exemplares de cada tipo foram sacrificados em clorofórmio e montados de acordo com as regras entomológicas. Uma parte da coleção de hemípteros foi identificada com o auxílio do Prof $^{\circ}$ Dr. Roberto Antonio Zucchi do Departamento de Entomologia da ESALQ (Escola Superior de Agricultura Luiz de Queiroz -USP). Os exemplares das famílias Pentatomidae e Coreidae foram enviados para a Universidade Federal do Rio Grande do Sul e identificados pela Prof ${ }^{a}$ Dra Jocélia Grazia e Prof. ${ }^{\circ}$ Dr.José Antonio Marin Fernandes respectivamente, os exemplares das famílias Miridae, Rhopalidae e Lygaeidae foram identificados pelo Prof ${ }^{\circ}$ Dr. Paulo Sergio Fiuza Ferreira da Universidade Federal de Viçosa.

A coleção de hemípteros foi numerada segundo um código de identificação que considerava o número do inseto por ordem de coleta:

01/01 =

01 - número de identificação do inseto;

01 - número de coleta.

\subsection{Isolamento, cultura e manutenção.}

Os hemípteros coletados eram anestesiados por clorofórmio, lavados com etanol $70 \%$ e dissecados para separar as glândulas salivares e intestinos para exame quanto à presença de tripanossomatídeos. Os insetos eram colocados em superfície de vidro para a remoção das asas e patas com tesoura. Em seguida, com o auxílio de um estilete de ponta chata introduzido no pró-tórax separávamos 
por simples tração a porção cefálica liberando as glândulas salivares. Estas eram transferidas para uma lâmina em PBS 0,01M estéril e levemente comprimidas entre lâmina e lamínula para, observação em microscópio de contraste de fase.

A seguir os conectivos do abdome eram cortados, o pronoto levantado e a musculatura torácica dorsal cortada para retirar 0 trato digestivo que era similarmente comprimido entre lâmina e lamínula para observação.

Todo material positivo para tripanossomatídeos era distribuído em 4 lâminas e fixado com metanol e também inoculado em tubos contendo meio de cultura bifásico. Este era composto de uma fase líquida de meio LIT (Camargo, 1964) acrescido de ampicilina e gentamicina numa concentração final de 4000 $\mu \mathrm{g} / \mathrm{ml}$ e uma base sólida de Blood Agar Base (Difco) 4\%. Os tubos eram mantidos em estantes inclinadas a $28^{\circ} \mathrm{C}$ durante 2 dias após o que eram examinados à procura de flagelados. Culturas negativas eram mantidas em cultivo por ainda 7 dias.

Para eliminação de fungos, culturas contendo parasitas eram inoculadas em tubos de vidro em U. Periodicamente recolhíamos amostras da extremidade do tubo oposta à da inoculação para observação microscópica. Quando apenas flagelados estavam presentes alíquotas eram inoculadas em LIT e mantidas a $28^{\circ} \mathrm{C}$.

Culturas limpas de leveduras e fungos eram criopreservadas em nitrogênio líquido (Campaner, 1991). 
Composição do meio LIT

Liver Infusion Tryptose serum medium

\begin{tabular}{lc}
\hline Componentes & $\mathbf{g} / \mathbf{l}$ \\
\hline Infuso de fígado (Difco) & 5 \\
Triptose & 5 \\
$\mathrm{NaCl}$ & 4 \\
$\mathrm{KCl}$ & 0,4 \\
$\mathrm{Na}_{2} \mathrm{PO}_{4}$ & 8 \\
$\mathrm{Glicose}^{*} \mathrm{Hemina}$ & 2 \\
${ }^{* *}$ Soro bovino & 0,01 \\
\hline pH 7,2 ajustado com $\mathrm{HCl} 2 \mathrm{~N}$ & $100 \mathrm{ml}$ \\
${ }^{*}$ Previamente dissolvido em NaOH $0,1 \mathrm{~N}$ & \\
${ }^{* *}$ inativado a $68^{\circ} \mathrm{C}$ por 1 hora & \\
O meio era esterilizado por filtração em um filtro Millipore $02 \mu \mathrm{m}$ &
\end{tabular}

\subsection{Morfologia e Morfometria}

As lâminas positivas de hemípteros fitófagos, coradas com Giemsa, foram examinadas por microscopia óptica utilizando o programa de computação Metamorph Imagining System versão 3.0 para Microsoft Windows $95^{\mathrm{TM}}$ e listados/calculados no programa Microsoft Excel 97. De cada lâmina eram fotografados 30 flagelados em média, que eram medidos quanto ao:

1. Comprimento do corpo;

2. Comprimento do flagelo livre;

3. Distância do cinetoplasto à extremidade anterior do corpo.

Com estas medidas foram determinados a média aritmética $(M)$, para estimar a média populacional da amostra, e o desvio padrão (dp), para avaliar a medida da variabilidade amostral. 


\subsection{Extração do DNA de tripanossomatídeos}

Os esfregaços fixados com metanol foram recobertos com $35 \mu$ de SDS $0,002 \%$, raspados com a ponteira de uma micropipeta e então transferidos para um tubo Eppendorf. Esta suspensão foi incubada para digestão com Proteinase $\mathrm{K}$ $\left(100 \mathrm{mg} / \mathrm{ml}\right.$ ) a $55^{\circ} \mathrm{C}$ por 01 hora e inativado por $10^{\prime}$ a $95^{\circ} \mathrm{C}$. Os tubos Eppendorf foram centrifugados por 4 minutos e conservados a $-20^{\circ} \mathrm{C}$. Em seguida $3 \mu \mathrm{l}$ do sobrenadante foi utilizados para amplificação por PCR conforme descrito por Serrano et al., (1999b).

\subsection{PCR}

A amplificação por PCR foi feita em $50 \mu l$ da reação de mistura: $3 \mu \mathrm{l}$ do DNA extraído conforme protocolo para extração de DNA descrito em 2.4; 0,2 mM de cada dNTP, 2,0 $\mu \mathrm{M}$ de cada iniciador, PSL1 e PSL2, Buffer para PCR 10X contendo 1,5mM MgCl2 e 2,5 unidades de Taq DNA polimerase (Gibco-BRL). Para amplificações de todos os tripanossomatídeos, Try-SLPCR, as reações foram submetidas a 30 ciclos de: $1 \mathrm{~min}$ a $94^{\circ}: \mathrm{C}, 1 \mathrm{~min}$ a $48^{\circ} \mathrm{C}$ e $1 \mathrm{~min}$ a $72^{\circ} \mathrm{C}$ com uma extensão final de $10 \mathrm{~min}$ a $72^{\circ} \mathrm{C}$. Para cada conjunto de reações um tubo contendo DNA de $P$. serpens (TCC-USP) e um tubo sem DNA foram utilizados como controle positivo e branco, respectivamente (Serrano et al., 1999a).

Oligonucleotídeos gênero específicos foram desenhados por comparação das seqüências do SL RNA de P. serpens; Jma, isolado de Jatropha macrantha (TCC - USP \# 060); Aca, isolado de Allamanda cathartica (TCC - USP \# 083); Cbe, de Citrus bergamia (TCC - USP \#233); Ech, isolado de Euphorbia characias (TCC - USP \# 066) (Nunes et al., 1995); EM1 e Hart1 (Sturn et al, 1995) de Palmae e alinhadas com vários outros gêneros de tripanossomatídeos obtidos no GenBank. A localização e as seqüências dos oligonucleotídeos que foram empregadas como iniciadores para PCR (PSL1 e PSL2) ou como sondas na hibridação por "Southern blot" (SL3'), estão desenhadas na fig. 7. 


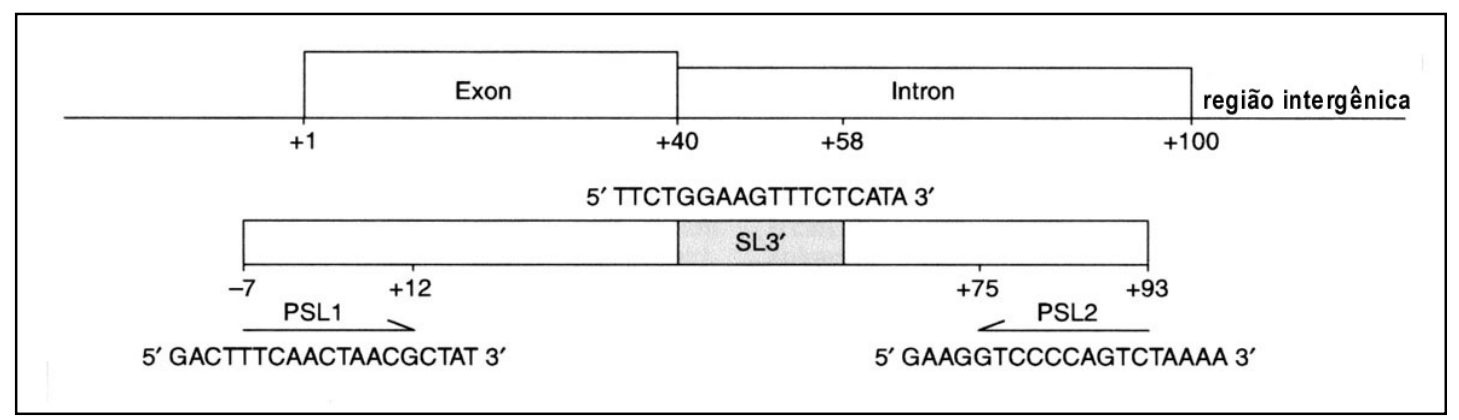

Fig. 7 - O oligonucleotídeo PSL1 é complementar à seqüência conservada em todos os gêneros de tripanossomatídeos. O oligonucleotídeo PSL2 é complementar à seqüência encontrada exclusivamente em Phytomonas. A sonda SL3' é complementar à seqüência $+40+58$ pb do íntron e específica para Phytomonas ssp.

Seqüência dos iniciadores:

PSL1 - 5' GACTTTCAACTAACGCTAT 3'

PSL2 - 5' GAAGGTCCCCAGTCTAAAA 3'

Seqüência da sonda:

SL3' - 5' TTCTGGAAGTTTCTCATA 3'.

Quando ocorreu inibição da reação do PCR, se procedeu a um retratamento da preparação do DNA já extraído da lâmina com Proteinase $\mathrm{K}$ ou se tentou inibição com $2 \%$ de BLOTTO (10\% de leite desnatado) na reação de PCR.

\subsection{Transferência de DNA (Southern blotting)}

O produto de DNA amplificado, cerca de $6 \mu$ foi submetido à eletroforese em gel de agarose $2 \%$ e colorido com brometo de etídio.

A $15 \mu \mathrm{l}$ do produto de PCR, adicionaram-se $85 \mu \mathrm{l}$ de TE, $100 \mu \mathrm{l}$ de solução desnaturante por 30', 200 $\mu$ l de solução neutralizante por 30' e 200 $\mu$ l de SSC 20X. A mistura foi então transferida para uma membrana (Hybond Amersham Pharmacia), tamponada com SSC 2X, em um aparelho Bio-Dot da Bio Rad. Após a transferência, os fragmentos foram fixados à membrana por exposição à luz UV no aparelho $W$-crosslinker $\left(12000 \mu \mathrm{j} / \mathrm{cm}^{2}\right)$. 
Solução desnaturante

Solução neutralizante

$\begin{array}{llllll}0,5 \mathrm{M} & \mathrm{NaCl} & 87,6 \mathrm{~g} & 1,5 \mathrm{M} & \mathrm{NaCl} & 87,6 \mathrm{~g} \\ 0,5 \mathrm{M} & \mathrm{NaOH} & 20,0 \mathrm{~g} & 0,5 \mathrm{M} & \text { Tris- } \mathrm{HCL} & 60,5 \mathrm{~g} \\ \mathrm{H}_{2} \mathrm{O} \text { destilada para } 11 & & \mathrm{pH} 7,5 & & \\ & & & \end{array}$

Autoclavar

Autoclavar

\subsection{Fosforilação do oligonucleotídeo}

Para fosforilação do oligonucleotídeo fervemos $3 \mu$ l do oligo SL3' (240ng/ $\mu \mathrm{l}$ ); e acrescentamos $12,0 \mu \mathrm{l}$ de $\mathrm{H}_{2} \mathrm{O}, 5,0 \mu \mathrm{l}$ de Buffer $5 \mathrm{x}, 5,0 \mu \mathrm{l}$ de $\left[\gamma{ }^{32} \mathrm{P}\right]$ dATP (Amersham, $3.000 \mathrm{Ci} / \mathrm{mmol}$ ) e $1 \mu \mathrm{l}$ de T4 Kinase Polynucleotidyl, deixar na estufa $37^{0} \mathrm{C}$ por 1 ou 2 horas, de acordo com Maniatis, (1982).

\subsection{Reações de hibridização, lavagem e processamento das membranas.}

Nas reações de pré-hibridação dos "dot blots" utilizamos: SSC 5X, Caseina $2 \%, \mathrm{~N}$-Lauril Sarcosine $0,01 \%$ e SDS $0,002 \%$. A membrana era colocada numa cuba de plástico junto com a solução de pré-hibridação a $37^{\circ} \mathrm{C}$ por 1 hora com agitação.

Para a hibridação, o oligonucleotídeo marcado (SL3') em solução de hibridação era incubado com a membrana por 16 horas, $37^{\circ} \mathrm{C}$ sob agitação. Em seguida a membrana era lavada com SSC $6 \mathrm{X}$ por duas vezes por $15^{\prime}$ à temperatura ambiente, depois com SSC $6 \mathrm{X}$ por duas vezes $15^{\prime}$ a $50^{\circ} \mathrm{C}$, sob agitação. Secadas com um papel de filtro após as lavagens, as membranas eram expostas a filmes de Raios-X (Kodak-T-Mat) por períodos de 72 a 96 horas a $-80^{\circ}$ C com tela amplificadora.

Os filmes eram processados de acordo com as instruções do fabricante. 
Para reutilização dos "dot blots" em novas reações, as sondas de reações precedentes eram removidas com $\mathrm{NaOH} 0.4 \mathrm{~N}$ por $30^{\circ}$ sob agitação a $43^{\circ} \mathrm{C}$ e em seguida lavadas duas ou três vezes com SSC $2 \mathrm{X}$ por $15^{\prime}$ sob agitação a temperatura ambiente. 
3. Resultados 


\subsection{Levantamento e Identificação das Espécies de Insetos Hemípteros}

\section{Fitófagos.}

Foram realizadas 37 coletas em várias localidades no estado de Rondônia entre maio de 1998 e janeiro de 1999, abrangendo as duas estações climáticas: o inverno (estação das águas, setembro a maio) e o verão (estação da seca de junho a agosto), Tabela 1.

Tabela 1 - Hemípteros coletados em Rondônia, durante o período de 98/99

\begin{tabular}{c|cccccccccc}
\hline Mês & mai & jun & jul & ago & set & out & Nov & Dez & jan & Total \\
\hline Coletas & 04 & 04 & 03 & 05 & 04 & 07 & 02 & 06 & 02 & 37 \\
Total ins & 35 & 42 & 16 & 28 & 30 & 23 & 16 & 25 & 28 & 244 \\
\hline
\end{tabular}

Distribuição de hemípteros fitófagos, coletados no estado de Rondônia, durante o ano.

Foram enviados para identificação 17 hemípteros cujas duplicatas estão conservadas no CIBEBI - Centro Interdepartamental de Biologia e Biotecnologia da Universidade Federal do Estado de Rondônia.

\subsection{Distribuição dos hemípteros fitófagos infectados por} tripanossomatídeos nas duas estações climáticas regionais

O número de hemípteros coletados nas duas estações climáticas de Rondônia está compilado, por família, na Tabela 2.

Tabela 2 - Hemípteros coletados em Rondônia nas duas estações climáticas.

\begin{tabular}{|c|c|c|c|c|c|c|c|c|c|}
\hline & & \multicolumn{8}{|c|}{ Família de Hemíptero } \\
\hline Estação do ano & Órgão & $\mathrm{Co}$ & $\mathrm{Pe}$ & Ly & $\mathrm{La}$ & $\mathrm{Mi}$ & $\mathrm{Rh}$ & $\mathrm{Re}$ & Total \\
\hline \multirow{5}{*}{ Inverno } & $\mathbf{E}$ & 105 & 12 & 30 & 01 & 02 & 0 & 03 & 153 \\
\hline & Gs & 04 & - & - & - & - & - & - & 04 \\
\hline & $\mathrm{Td}$ & 33 & - & 06 & 01 & - & - & 01 & 41 \\
\hline & $\mathrm{Gs} / \mathrm{Td}$ & 24 & - & - & - & - & - & - & 24 \\
\hline & $\%+$ & 57 & - & 20 & 100 & - & - & 33 & 44 \\
\hline \multirow{5}{*}{ Verão } & $E$ & 60 & 01 & 09 & 10 & 09 & 02 & 0 & 91 \\
\hline & Gs & 06 & - & - & 01 & - & - & - & 06 \\
\hline & $\mathrm{Td}$ & 21 & 01 & 02 & 06 & - & - & - & 30 \\
\hline & $\mathrm{Gs} / \mathrm{Td}$ & 03 & - & - & - & - & - & - & 03 \\
\hline & $\%+$ & 50 & 100 & 22 & 70 & - & - & - & 44 \\
\hline \multirow{5}{*}{ Total } & $E$ & 125 & 13 & 39 & 11 & 11 & 02 & 03 & 244 \\
\hline & Gs & 10 & - & - & 01 & - & - & - & 11 \\
\hline & $\mathrm{Td}$ & 54 & 01 & 08 & 07 & - & - & 01 & 71 \\
\hline & $\mathrm{Gs} / \mathrm{Td}$ & 25 & - & - & - & - & - & - & 25 \\
\hline & $\%+$ & 54 & 07 & 20 & 72 & - & - & 33 & 44 \\
\hline
\end{tabular}

E, examinados; Gs, glândula salivar; Td, trato digestivo; Gs/Td, glândula salivar e trato digestivo; \%+, porcentagem de positivos. Co, Coreidae; Pe, Pentatomidae; $L y$, Lygaeidae; La, Largidae; Rh, Rhopalidae; Mi, Miridae; Re, Reduvidae. 
No inverno (9 meses) entre os 153 hemípteros adultos coletados, 68 (44\%) estavam positivos. No verão ( 3 meses) entre os 91 hemípteros adultos coletados 40 (44\%) estavam positivos. As porcentagens de insetos infectados nas duas estações climáticas foram, portanto, bastante próximas, o que parece sugerir que as infecções estejam presentes o ano todo, o que contrasta com regiões temperadas e frias onde as taxas de infecção são menores no inverno.

Entre os 108 hemípteros parasitados por tripanossomatídeos inferiores, $83,4 \%$ eram da família Coreidae, $7,4 \%$ da família Largidae, $7,4 \%$ da família Lygaeidae, $0,9 \%$ da família Pentatomidae, $0,9 \%$ da família Reduvidae, $0 \%$ da família Rhopalidae e $0 \%$ da família Miridae.

A tabela 3 registra as espécies de hemípteros encontradas e, entre estas, as 13 espécies infectadas por tripanossomatídeos conforme aferido por microscopia dos órgãos indicados.

Tabela 3 - Prevalência de tripanossomatídeos, segundo gênero e espécie, nas diferentes famílias de hemípteros coletados em diversas regiões no estado de Rondônia.

\begin{tabular}{|c|c|c|c|c|c|c|}
\hline Família & Gênero/Espécie & $E$ & Gs & $\mathrm{Td}$ & Gs/Td & $\%$ \\
\hline \multirow{10}{*}{ Coreidae } & Hypselonotus fulvus & 74 & 4 & 24 & 6 & 46 \\
\hline & *Veneza stigma & 16 & & 6 & 9 & 93 \\
\hline & Veneza sp & 24 & 2 & 11 & 2 & 66 \\
\hline & ${ }^{*}$ Crinocerus sanctus & 33 & 4 & 9 & 2 & 48 \\
\hline & Sphictyrtus cryseis & 1 & & 1 & & 100 \\
\hline & ${ }^{*}$ Lucullia flavovittata stal & 2 & & & 2 & 100 \\
\hline & Phthia picta & 8 & & 2 & 1 & 37 \\
\hline & ${ }^{*}$ Phthia lunata & 5 & & 1 & 3 & 80 \\
\hline & ${ }^{*}$ Acanthocephala latipes & 2 & & 1 & & 50 \\
\hline & Total & 165 & 10 & 55 & 25 & 47 \\
\hline Largidae & ${ }^{*}$ Largus humilis & 10 & 1 & 7 & & 80 \\
\hline Miridae & $N I$ & 11 & & & & 0 \\
\hline Rhopalidae & Niesthrea sp & 2 & & & & 0 \\
\hline \multirow{2}{*}{ Pentatomidae } & Edessa rufomarginata & 6 & & & & 0 \\
\hline & Euchistus sp & 7 & & & & 0 \\
\hline Lygaeidae & $N I$ & 39 & & 8 & & 20 \\
\hline \multirow{2}{*}{ Reduvidae } & Arilus carinatus & 1 & & 1 & & 100 \\
\hline & Apromerus sp & 2 & & 1 & & 50 \\
\hline
\end{tabular}


A maioria dos insetos $(67 \%)$ apresentou flagelados somente no trato digestivo, $8 \%$ somente nas glândulas salivares e $25 \%$ no trato digestivo e glândulas salivares.

Entre os hemípteros fitófagos examinados 5 espécies (assinaladas com asterisco na Tabela 3) estão sendo descritas pela primeira vez como hospedeiras de flagelados.

\subsection{Tripanossomatídeos isolados de hemípteros}

Das 108 amostras positivas para tripanossomatídeos inoculadas em meio de cultura LIT, obtivemos apenas 05 isolados originários do trato digestivo ( tabela $4)$.

Tabela 4 - Cultura de tripanossomatídeos recuperadas de hemípteros de acordo com local de coleta.

\begin{tabular}{lllll}
\hline \multicolumn{1}{c}{ Local } & Cultura & Pl. de origem & Hemíptero & Família \\
\hline R de Moura & $23 / 66$ & Quiabo & H. fulvus & Coreidae \\
Cach.St.Antonio & $7 / 176$ & Floresta & L. humilis & Largidae \\
V.Eletronorte & $264 / 266$ & Araçá & Veneza $s p$ & Coreidae \\
V.Eletronorte & $264 / 302$ & Araçá & Veneza $s p$ & Coreidae \\
V.Eletronorte & $269 / 269$ & Araçá & Veneza $s p$ & Coreidae \\
\hline
\end{tabular}

A tabela 4 registra a plantas onde foram coletadas as espécies de hemípteros que geraram culturas positivas.

Estas culturas se encontram armazenadas em nitrogênio líquido no CEPEM - Centro de Pesquisas em Medicina Tropical de Rondônia, para posteriores testes.

\subsection{Morfologia e morfometria}

Dos insetos positivos foram feitos esfregaços dos órgãos infectados que foram corados com Giemsa para microscopia e análise morfométrica. 60 lâminas escolhidas ao acaso foram examinadas e fotografadas. Segundo suas características morfológicas, os flagelados foram reunidos em 4 grupos: 


\subsubsection{Grupo 1 - (clique aqui para ver figuras do grupo 1)}

Constituído por promastigotas sem torção ao longo do corpo celular. A tabela 5 registra os flagelados desse grupo, as espécies hospedeiras de origem e o código de identificação da imagem.

Os resultados das medidas estão relacionados na tabela 6. As medidas extremas foram: para o comprimento do corpo, mínimo de 8,9 $\mu \mathrm{m}$, e máximo de $24,1 \mu \mathrm{m}$; para o comprimento do flagelo livre, $4,8 \mu \mathrm{m}$ de mínimo e $34,9 \mu \mathrm{m}$ de máximo.

Tabela 5 - Tripanossomatídeos do Grupo 1.

\begin{tabular}{ll}
\hline Hemíptero & Código \\
\hline Crinocerus sanctus & $282 \mathrm{td}$ \\
Crinocerus sanctus & $132 \mathrm{td}$ \\
Crinocerus sanctus & $120 \mathrm{td}$ \\
Hypselonoltus fulvus & $242 \mathrm{gs}$ \\
Phthia picta & $31 \mathrm{gs}$ \\
Hypselonltus fulvus & $83 \mathrm{td}$ \\
Veneza stigma & $25 \mathrm{td}$ \\
Veneza sp & $287 \mathrm{td}$ \\
Veneza sp & $294 \mathrm{td}$ \\
Hypselonltus fulvus & $239 \mathrm{td}$ \\
Hypselonltus fulvus & $132 \mathrm{td}$ \\
Hypselonltus fulvus & $148 \mathrm{td}$ \\
Hypselonltus fulvus & $180 \mathrm{td}$ \\
Hypselonltus fulvus & $243 \mathrm{td}$ \\
Crinicerus sanctus & $100 \mathrm{td}$ \\
Veneza stigma & $280 \mathrm{td}$ \\
Veneza sp & $281 \mathrm{td}$ \\
Hypselonltus fulvus & $86 \mathrm{td}$ \\
Hypselonltus fulvus & $231 \mathrm{td}$ \\
\hline
\end{tabular}

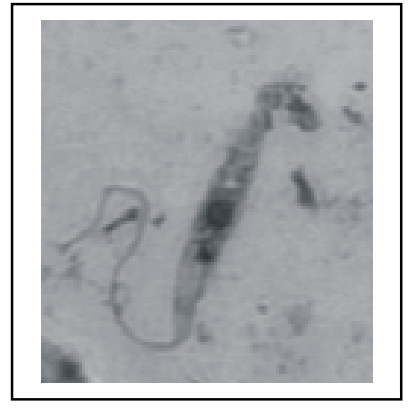

180td Hypselonltus fulvus

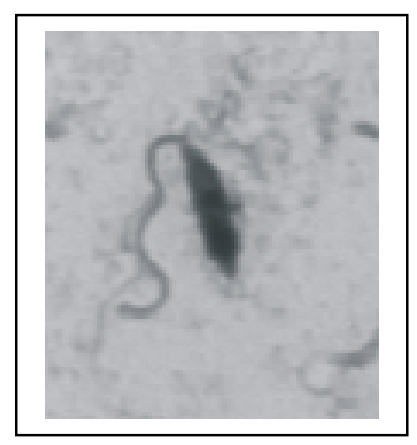

282td Crinocerus sanctus 
Tabela 6 - Medidas em $\mu \mathrm{m}$ dos tripanossomatídeos do Grupo1.

\begin{tabular}{|c|c|c|c|}
\hline Isolado & c.c. & c.f. & c.a. \\
\hline $282 \mathrm{td}$ & $12,{ }^{a} \pm 3,3^{b}(5,6-19,2)^{c}$ & $14,4 \pm 4,1(6,9-23,1)$ & $3,3 \pm 0,7(2,1-4,7)$ \\
\hline $132 \mathrm{td}$ & $13,3 \pm 2,3(7,9-17,8)$ & $11,5 \pm 4,0(2,3-18,8)$ & $2,4 \pm 0,6(1,0-3,9)$ \\
\hline $120 \mathrm{td}$ & $11,1 \pm 2,4(5,4-16,1)$ & $9,9 \pm 3,9(3,4-19,9)$ & $2,8 \pm 0,6(1,6-3,9)$ \\
\hline 242gs & $8,9 \pm 2,7(4,4-14,4)$ & $27,4 \pm 6,6(11,1-39,6)$ & $4,5 \pm 0,9(2,9-5,9)$ \\
\hline 31gs & $19,3 \pm 4,1(12,4-24,9)$ & $25,3 \pm 8,5(5,7-36,5)$ & $5,0 \pm 1,3(3,5-9,0)$ \\
\hline $83 \mathrm{td}$ & $14,0 \pm 3,8(10,1-25,3)$ & $13,4 \pm 3,1(5,2-17.0)$ & $3,4 \pm 0,9(1,9-5,5)$ \\
\hline $25 \mathrm{td}$ & $12,4 \pm 2,6(12,5-14,0)$ & $12,3 \pm 3,4(9,9-14,7)$ & $3,7 \pm 0,6(2,9-3,6)$ \\
\hline $287 \mathrm{td}$ & $20,2 \pm 4,0(12,2-29,6)$ & $29,5 \pm 6,9(14,6-44,6)$ & $6,5 \pm 2,02,5-11,6)$ \\
\hline $294 \mathrm{td}$ & $24,1 \pm 9,2(13,9-43,1)$ & $8,7 \pm 3,0(5,0-13,1)$ & $5,6 \pm 2,0(3,0-9,5)$ \\
\hline $239 \mathrm{gs}$ & $12,8 \pm 2,6(6,9-21,0)$ & $12,6 \pm 4,0(4,0-21,8)$ & $3,3 \pm 0,6(2,0-5,2)$ \\
\hline $180 t d$ & $12,4 \pm 1,9(7,6-15,6)$ & $16,1 \pm 3,7(7,7-21,4)$ & $2,9 \pm 0,4(1,5-3,9)$ \\
\hline $243 \mathrm{td}$ & $25,6 \pm 5,3(13,4-37,9)$ & $26,8 \pm 1,2(6,0-36,0)$ & $5,2 \pm 1,8(2,2-9.3)$ \\
\hline 100 td & $9,5 \pm 1,7(7,8-14,2)$ & $9,2 \pm 2,8(5,8-16,3)$ & $3,1 \pm 0,8(2,2-5,3)$ \\
\hline $280 \mathrm{td}$ & $20,3 \pm 4,0(15,0-25,7)$ & $22,3 \pm 4,2(14,5-28,4)$ & $3,9 \pm 0,7(2,9-5,2)$ \\
\hline $281 \mathrm{td}$ & $20,6 \pm 3,9(13,1-31,4)$ & $34,9 \pm 6,6(19,0-45,1)$ & $6,6 \pm 2,0(2,4-10,6)$ \\
\hline $86 \mathrm{td}$ & $22,3 \pm 3,7(15,7-30,2)$ & $19,8 \pm 6,5(11,1-37,9)$ & $5,5 \pm 1,3(3,0-8,2)$ \\
\hline $231 \mathrm{td}$ & $11,8 \pm 1,8(6,5-15,9)$ & $14,1 \pm 2,9(8,3-20,6)$ & $2,6 \pm 0,4(1,9-3,8)$ \\
\hline
\end{tabular}

3.4.2 Grupo 2 (clique aqui para ver figuras do grupo 2)

No Grupo 2 foram agrupados promastigotas com torção ao longo do corpo celular.

A tabela 7 registra os flagelados deste grupo, as espécies hospedeiras, órgão de origem e código de identificação. Os resultados das medidas estão registrados na tabela 8 . As medidas extremas para o comprimento do corpo foram $11,8 \mu \mathrm{m}$ e $73,6 \mu \mathrm{m}$ e para o comprimento do flagelo livre $2,2 \mu \mathrm{m}$ e $34,8 \mu \mathrm{m}$. 
Tabela 7 - Tripanossomatídeos do grupo 2.

\begin{tabular}{lc}
\hline \multicolumn{1}{c}{ Hemíptero } & Código/Órgão \\
\hline Hypselonoltus fulvus & $24 \mathrm{gs}$ \\
Veneza sp & $294 \mathrm{td}$ \\
Veneza sp & $302 \mathrm{td}$ \\
Hypselonoltus fulvus & $236 \mathrm{gs}$ \\
Hypselonoltus fulvus & $236 \mathrm{td}$ \\
Veneza stigma & $246 \mathrm{td}$ \\
Veneza stigma & $238 \mathrm{td}$ \\
Veneza stigma & $281 \mathrm{td}$ \\
Crinicerus sanctus & $101 \mathrm{td}$ \\
$\mathrm{NI}$ & $212 \mathrm{td}$ \\
$\mathrm{NI}$ & $213 \mathrm{td}$ \\
NI & $216 \mathrm{td}$ \\
Hypselonoltus fulvus & $234 \mathrm{td}$ \\
Hypselonoltus fulvus & $190 \mathrm{gs}$ \\
Hypselonoltus fulvus & $190 \mathrm{td}$ \\
Ni & $206 \mathrm{td}$ \\
Veneza sp & $283 \mathrm{td}$ \\
Veneza stigma & $166 \mathrm{td}$ \\
Veneza stigma & $165 \mathrm{td}$ \\
Veneza stigma & $276 \mathrm{td}$ \\
Veneza sp & $265 \mathrm{td}$ \\
Veneza sp & $269 \mathrm{td}$ \\
Hypselonoltus fulvus & $91 \mathrm{gs}$ \\
Hypselonoltus fulvus & $244 \mathrm{td}$ \\
Hypselonoltus fulvus & $87 \mathrm{td}$ \\
Hypselonoltus fulvus & $232 \mathrm{td}$ \\
Venezasp & $300 \mathrm{td}$ \\
Veneza sp & $287 \mathrm{td}$ \\
Hypselonoltus fulvus & $148 \mathrm{td}$ \\
Hypselonoltus fulvus & $238 \mathrm{td}$ \\
Veneza sp & $267 \mathrm{gs}$ \\
\hline
\end{tabular}

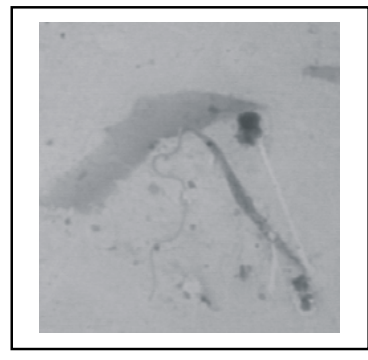

165td Veneza stigma

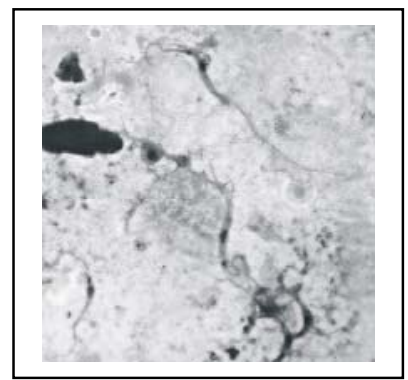

190gs Hypselonoltus fulvus 
Tabela 8 - Medidas em $\mu \mathrm{m}$ dos tripanossomatídeos do Grupo 2.

\begin{tabular}{|c|c|c|c|}
\hline isolado & C.C. & c.f. & c.a. \\
\hline $24 \mathrm{gs}$ & $13,0^{a} \pm 2,0^{b}(9,6-17,7)^{c}$ & $13,9 \pm 3,6(7,2-22,6)$ & $2,6 \pm 0,6(3,9-16,1)$ \\
\hline $294 t d$ & $24,1 \pm 9,2(14-43,2)$ & $8,7 \pm 3,0(5,0-13,2)$ & $5,6 \pm 2,0(3,1-9,6)$ \\
\hline $302 t d$ & $19,9 \pm 3,1(13,1-28,8)$ & $27,0 \pm 6,1(9,7-34,4)$ & $4,6 \pm 1,7(2,3-9,7)$ \\
\hline $236 g s$ & $15,1 \pm 4,1(9,2-27,3)$ & $31,7 \pm 8,6(1,7-5,4)$ & $9,0 \pm 2,6(3,3-15,2)$ \\
\hline $236 t d$ & $19,8 \pm 6,3(9,3-37,7)$ & $17,7 \pm 3,9(8,3-26,8)$ & $3,9 \pm 1,0(2,3-6,8)$ \\
\hline $246 \mathrm{td}$ & $24,6 \pm 7,1(12,0-39,8)$ & $24,3 \pm 9,8(7,6-42,3)$ & $3,7 \pm 1,2(2,1-7,6)$ \\
\hline 238td & $18,6 \pm 4,9(7,9-31,1)$ & $15,1 \pm 4,7(8,4-28,5)$ & $4,2 \pm 1,1(2,1-6,7)$ \\
\hline 281gs & $23,8 \pm 4,5(16,6-39,2)$ & $30,7 \pm 10,3(7,4-45,9)$ & $6,3 \pm 2,2(3,7-10,7)$ \\
\hline 101gs & $23,7 \pm 5,2(12,6-35,2$ & & \\
\hline $212 t d$ & $12,7 \pm 2,5(6,7-16,6)$ & $14,8 \pm 4,1(7,1-22,5)$ & $3,1 \pm 10,6(1,6-4,6)$ \\
\hline $213 t d$ & $13,2 \pm 2,7(8,9-20,7)$ & $11,8 \pm 3,3(7,1-20,2)$ & $3,6 \pm 0,6(2,5-5,0)$ \\
\hline $216 t d$ & $20,3 \pm 3,6(12,8-29,3)$ & $17,0 \pm 4,8(8,7-27,1)$ & $3,9 \pm 1,9(2,2-6,4)$ \\
\hline $234 t d$ & $16,0 \pm 3,7(10,8-31,3)$ & $10,5 \pm 4,1(4,4-20,7)$ & $3,2 \pm 0,8(1,6-5,5)$ \\
\hline $190 \mathrm{gs}$ & $37,0 \pm 12,8(17,6-73,6)$ & $4,3 \pm 0,9(2,4-6,4)$ & $8,4 \pm 2,7(3,5-14,0)$ \\
\hline 190td & $35,0 \pm 12,8(17,6-73,6)$ & $8,4 \pm 2,7(3,5-14,0)$ & $4,3 \pm 0,9(2,9-6,4)$ \\
\hline $206 t d$ & $11,8 \pm 2,8(6,6-21,7)$ & $6,9 \pm 4,1(3,8-14,9)$ & $2,9 \pm 1,1(1,3-6,6)$ \\
\hline $283 t d$ & $20,2 \pm 5,4(13,3-37,3)$ & $18,9 \pm 6,0(11,2-32,9)$ & $3,7 \pm 0,8(2,3-5,6)$ \\
\hline $166 t d$ & $20,2 \pm 4,6(12,8-27,6)$ & $13,8 \pm 7,9(8,0-25,4)$ & $3,9 \pm 0,9(2,4-5,5)$ \\
\hline $165 t d$ & $20,5 \pm 4,0(8,4-30,2$ & $20,4 \pm 5,9(7,9-32,1)$ & $4,5 \pm 1,6(5,5-6,5)$ \\
\hline $276 \mathrm{td}$ & $27,1 \pm 11,4(13,1-52,0)$ & $21,3 \pm 5,3(13,1-36,8)$ & $4,6 \pm 1,2(2,8-7,5)$ \\
\hline $265 t d$ & $24,5 \pm 5,4(16,3-34,5)$ & $34,8 \pm 7,5(19,6-48,9)$ & $4,6 \pm 1,1(2,7-6,9)$ \\
\hline $269 t d$ & $23,1 \pm 5,2(12,2-33,9)$ & $31,3 \pm 7,7(9,3-45,8)$ & $3,8 \pm 0,7(2,5-5,1)$ \\
\hline 91gs & $23,9 \pm 5,6(13,6-32,3)$ & $7,8 \pm 1,9(3,8-10,9)$ & $3,2 \pm 0,8(1,9-5,3)$ \\
\hline $244 t d$ & $25,3 \pm 5,6(13,7-35,8)$ & $2,2 \pm 2,1(3,8-10,9)$ & $3,3 \pm 0,8(2,0-5,4)$ \\
\hline $87 \mathrm{td}$ & $19,1 \pm 3,6(11,8-25,4)$ & $15,5 \pm 3,5(10,8-23,3)$ & $4,3 \pm 1,7(2,0=8,9)$ \\
\hline $232 t d$ & $19,4 \pm 4,4(9,6-30,9)$ & $13,8 \pm 3,2(6,2-20,4)$ & $4,1 \pm 0.8(2,5-6,0)$ \\
\hline $300 t d$ & $12,8 \pm 2,6(7,4-20,2)$ & $10,6 \pm 4,0(4,3-21,7)$ & $3,2 \pm 0,8(1,9-5,2)$ \\
\hline $287 t d$ & $20,2 \pm 4,0(12,2-29,6)$ & $29,5 \pm 6,9(14,6-44,6)$ & $6,5 \pm 2,02,5-11,6)$ \\
\hline $148 t d$ & $18,4 \pm 3,0(13,2-27,7)$ & $22,6 \pm 6.6(13,6-34,5)$ & $3,6 \pm 0,9(1,9-5,6)$ \\
\hline 267gs & $22,4 \pm 4,1(16,4-30,9)$ & $30,7 \pm 6,9(16,7-44,0)$ & $6,6 \pm 1,9(4,1-11,1)$ \\
\hline
\end{tabular}

a, média aritmética; $b$, desvio padrão; $c$, valores mínimos e máximos; c.c, comprimento do corpo; c.f., comprimento do flagelo; c.a., distância do cinetoplasto à extremidade do corpo.

3.4.3 Grupo 3 (clique aqui para ver figuras do grupo 3)

O Grupo 3 apresenta tripanossomatídeos com acentuado polimorfismo. Formas promastigotas com flagelo livre e outras aflageladas de tamanho variado ocorrem em grande quantidade.

A tabela 9 relaciona os tripanossomatídeos deste grupo, as espécies hospedeiras, os órgãos de origem e o código de identidade.

Os resultados das medidas destes tripanossomatídeos estão relacionados na tabela 10. As medidas extremas foram de $11,0 \mu \mathrm{m}$ e $5,6 \mu \mathrm{m}$ para o flagelo quando presente e $28,3 \mu \mathrm{m}$ e $13,6 \mu \mathrm{m}$ para o comprimento do corpo 
Tabela 9 - Tripanossomatídeos do grupo 3

\begin{tabular}{ll}
\hline \multicolumn{1}{c}{ Hemípteros } & \multicolumn{1}{c}{ Código } \\
\hline Crinocerus sanctus & 103 \\
Veneza sp & $287 \mathrm{gs}$ \\
Hypselonoltus fulvus & $244 \mathrm{gs}$ \\
Hypselonoltus fulvus & $245 \mathrm{gs}$ \\
Veneza stigma & $247 \mathrm{gs}$ \\
Crinocerus sanctus & $148 \mathrm{gs}$ \\
$\mathrm{NI}$ & $204 \mathrm{gs}$ \\
$\mathrm{NI}$ & $207 \mathrm{gs}$ \\
Hypselonoltus fulvus & $243 \mathrm{gs}$ \\
\hline
\end{tabular}

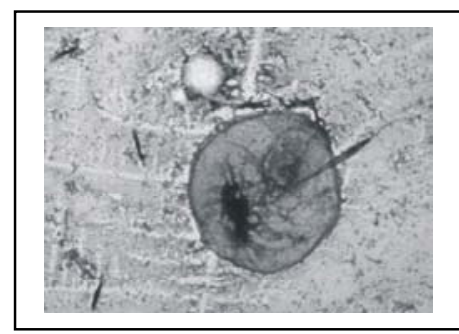

245gs Hypselonoltus fulvus

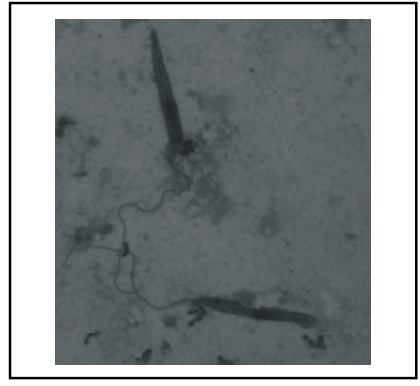

287gs Veneza sp

Tabela 10 - Medidas em $\mu \mathrm{m}$ dos tripanossomatídeos do Grupo 3.

\begin{tabular}{crrr}
\hline isolado & \multicolumn{1}{c}{ c.c. } & \multicolumn{1}{c}{ c.f. } & c.a. \\
\hline 103gs & $28,3^{\mathrm{a}} \pm 7,3^{\mathrm{b}}(17,4-42,1)^{\mathrm{c}}$ & $7,4 \pm 2,4(3,7-2,3)$ & $3,0 \pm 0,8(1,9-5,9)$ \\
& $5,4 \pm 1,0(3,9-7,0)$ & & \\
287gs & $24,2 \pm 6,8(13,0-40,1)$ & $5,6 \pm 1,3(3,4-7,7)$ & $4,1 \pm 0,83,0-6,0)$ \\
& $8,8 \pm 1,5(7,1-9,8)$ & & \\
$244 \mathrm{gs}$ & $25,0 \pm 6,1(10,5-35,2)$ & $7,4 \pm 1,8(3,3-11,7)$ & $3,5 \pm 0,8(2,1-5,4)$ \\
& $8,8 \pm 0,7(7,1-9,9)$ & & \\
$245 g s$ & $25,4 \pm 6,4(12,9-37,2)$ & $11,0 \pm 2,9(7,1-15,8)$ & $3,6 \pm 0,7(2,1-5,2)$ \\
& $8,5 \pm 1,6(6,2-13,0)$ & & \\
$247 g s$ & $21,2 \pm 6,7(10,7-33,8)$ & $6,4 \pm 2,1(5,0-11,9)$ & $3,4 \pm 0,6(2,4-4,6)$ \\
& $8,8 \pm 1,2(6,7-10,9)$ & & \\
148gs & $13,6 \pm 1,1(11,5-15,6)$ & & \\
$204 g s$ & $4,7 \pm 0,9(2,8-6,8)$ & & $3,1 \pm 1,1(2,0-7,8)$ \\
207 td & $17,0 \pm 5,0(8,8-28,5)$ & $7,2 \pm 2,3(4,1-11,8)$ & $2,2 \pm 0,3(1,4-3,1)$ \\
& $7,2 \pm 1,4(5,2-11,2)$ & & $3,3 \pm 0,8(1,9-5,5)$ \\
$243 g s$ & $22,9 \pm 5,4(13,1-33,3)$ & $7,5 \pm 1,4(4,1-10,3)$ & \\
& $8,4 \pm 1,3(6,3-11,6)$ & & \\
\hline
\end{tabular}

a, média aritmética; $b$, desvio padrão; $c$, valores mínimos e máximos; c.c, comprimento do corpo; c.f., comprimento do flagelo; c.a.,distância do cinetoplasto à extremidade do corpo. 
3.4.4 Grupo 4 (clique aqui para ver figuras do grupo 4)

O Grupo 4 apresenta tripanossomatídeos com formas promastigotas com flagelo livre ao lado de coanomastigotas. As imagens correspondem às formas coanomastigotas.

A tabela 11 registra tripanossomatídeos deste grupo, com as espécies e órgãos de origem e seu código de identidade. Os resultados das medidas destes tripanossomatídeos estão relacionados na tabela 12. As medidas extremas foram de $10,6 \mu \mathrm{m}$ e $7,5 \mu \mathrm{m}$ para o comprimento do corpo e $9,3 \mu \mathrm{m}$ e $3,7 \mu \mathrm{m}$ no comprimento do flagelo livre.

Tabela 11 -Tripanossomatídeos do grupo 4.

\begin{tabular}{lcc}
\hline \multicolumn{1}{c}{ Hemíptero } & Código & Forma \\
\hline Veneza sp & 288td & $\mathrm{P}, \mathrm{C}$ \\
Lygaeidae, sp. não identificada & 176td & $\mathrm{P}, \mathrm{C}$ \\
Arilus carinatus & 296td & $\mathrm{P}, \mathrm{C}$ \\
Phthia lunata & 152td & $\mathrm{P}, \mathrm{C}$ \\
\hline
\end{tabular}

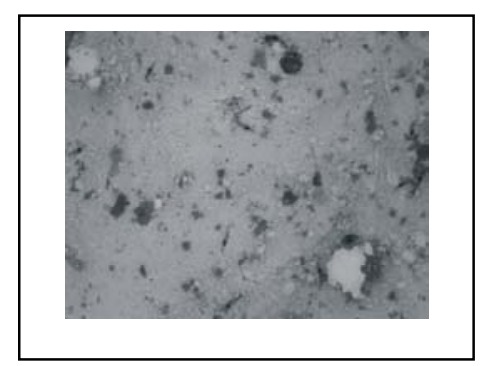

288td Veneza sp

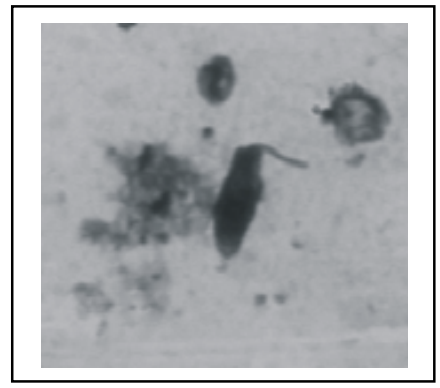

296td Arilus carinatus

Tabela 12 - Medidas em $\mu \mathrm{m}$ dos tripanossomatídeos do Grupo 4.

\begin{tabular}{cccc}
\hline Isolado & C.C & c.f & c.a \\
\hline 288 td & $7,5^{\mathrm{a}} \pm 1,4^{\mathrm{b}}(4,5-12,0)^{\mathrm{c}}$ & $3,7 \pm 1,7(1,3-10,0)$ & $2,4 \pm 0,6(1,4-4,0)$ \\
$176 \mathrm{td}$ & $10,6 \pm 1,8(6,8-13,9)$ & $7,8 \pm 2,0(3,0-11,0)$ & $2,8 \pm 0,7(1,7-4,5)$ \\
$296 \mathrm{td}$ & $8,0 \pm 1,9(5,8-13,4)$ & $5,6 \pm 1,7(3,0-9,3)$ & $3,4 \pm 0,8(2,8-4,7)$ \\
152td & $10,2 \pm 1,1(8,6-12,2)$ & $9,3 \pm 2,1(5,7-12,4)$ & $3,9 \pm 0,7(2,6-4,4)$ \\
\hline a, média aritmética; $\quad$ b, desvio padrão; c, valores minimos e máximos; c.c, \\
comprimento do corpo; c.f., comprimento do flagelo; c.a.,distância do cinetoplasto à \\
extremidade do corpo.
\end{tabular}




\subsection{Marcadores moleculares}

Foram analisadas 178 lâminas contendo esfregaços de tubo digestivo e glândulas salivares de hemípteros fitófagos e hemípteros predadores, fixados com metanol. Destas 178 lâminas 141 apresentavam parasitas à microscopia de luz. $O$ DNA foi recuperado das lâminas e amplificados por Try - SLPCR. Foram encontradas 105 amostras positivas para tripanossomatídeos. Exemplos dos resultados estão na figura 8. O produto amplificado por Try - SLPCR foi hibridado com a sonda SL3'. Foram encontradas 42 amostras positivas, que representam o gênero Phytomonas.

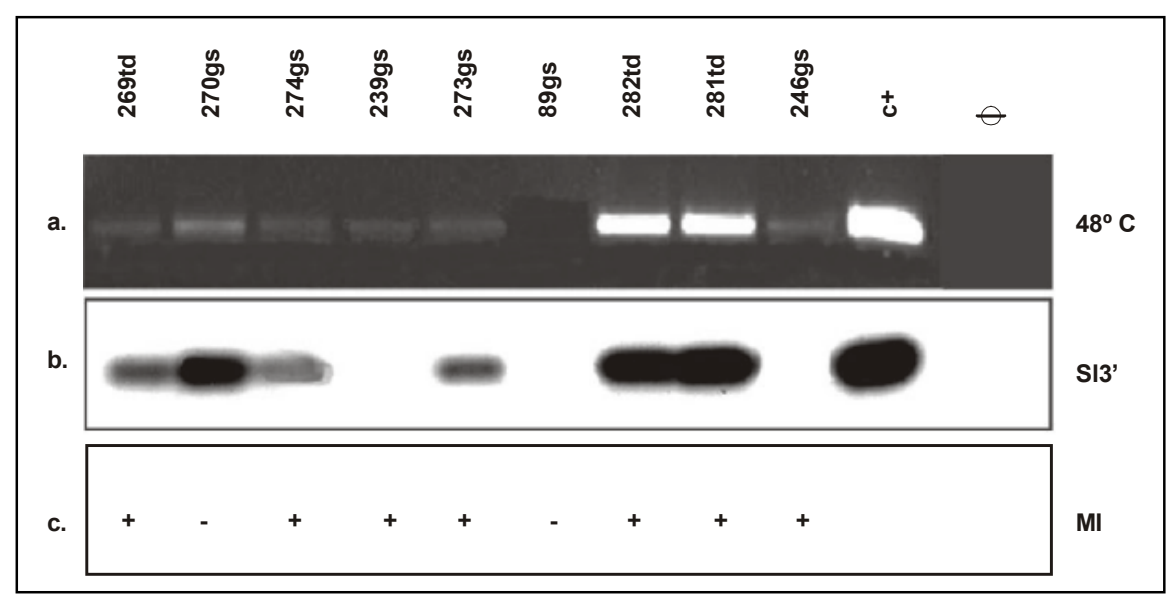

Fig. 08 - Fotos representativas de amplificação e hibridação.

a)Try - SLPCR Amplificação de fragmentos do DNA de flagelados recuperados de laminas digeridos com Proteinase $\mathrm{K}$ e da amplificação/repareamento a $48^{\circ} \mathrm{C}$.

b) Hibridação do produto de amplificação por PCR das amostras processadas c).MI - Investigação microscópica.

$269 t d$, isolado de Veneza sp; $270 \mathrm{gs}$, isolado do hemíptero Veneza stigma; 274gs, isolado de Hypselonoltus fulvus; 239gs, isolado do hemíptero Hypselonoltus fulvus, 273gs, isolado do hemíptero Phthia lunata; 89gs, isolado do hemíptero Largus humilis; 282td; isolado do hemíptero Crinocerus sanctus, 281td, isolado de Veneza sp; 246gs, isolado de Phthia lunata; C+, para controle positivo foi utilizado o DNA genômico de amostra de $P$. serpens (TCC-USP \# 060); $\phi$, branco. 
Tabela 13 - Detecção de Phytomonas de hemípteros infectados com tripanossomatídeos à partir do DNA amplificado de glândulas salivares e tubo digestivo por Try-SLPCR e hibridação com a sonda SL3'.

\begin{tabular}{|c|c|c|c|c|c|c|c|}
\hline Cód. & Isol. & Família & Espécie & $\mathrm{Ml}$ & $\mathrm{F}$ & $\begin{array}{c}\text { Try-SL } \\
\text { PCR }\end{array}$ & SL3' \\
\hline $\mathrm{A} 1$ & $282 \mathrm{td}$ & Coreidae & Crinocerus sanctus & ++ & $\mathrm{P}$ & + & + \\
\hline A2 & $281 \mathrm{td}$ & Coreidae & Veneza sp & t++ & $P$ & + & + \\
\hline B2 & 287gs & Coreidae & Veneza sp & ++ & PA & + & + \\
\hline D1 & $243 t d$ & Coreidae & Hypselonoltus fulvus & + & $\mathrm{P}$ & + & + \\
\hline D3 & $244 t d$ & Coreidae & Hypselonoltus fulvus & + & $P$ & + & + \\
\hline D4 & $244 \mathrm{gs}$ & Coreidae & Hypselonoltus fulvus & + & $\mathrm{P}$ & + & + \\
\hline E4 & $272 \mathrm{gs}$ & Coreidae & Veneza stigma & + & $P$ & + & + \\
\hline E5 & $272 \mathrm{td}$ & Coreidae & Veneza stigma & + & $\mathrm{P}$ & + & + \\
\hline $\mathrm{F} 2$ & $274 g s$ & Coreidae & Phthia lunata & + & $P$ & + & + \\
\hline $\mathrm{F} 4$ & $275 \mathrm{gs}$ & Coreidae & Phthia lunata & + & $\mathrm{P}$ & + & + \\
\hline $\mathrm{H} 1$ & $280 \mathrm{gs}$ & Coreidae & Veneza stigma & +++ & $\mathrm{P}$ & + & + \\
\hline $\mathrm{J} 2$ & $236 \mathrm{gs}$ & Coreidae & Hypselonoltus fulvus & +++ & $\mathrm{P}$ & + & + \\
\hline J3 & $236 \mathrm{td}$ & Coreidae & Hypselonoltus fulvus & +++ & $P$ & + & + \\
\hline $\mathrm{J} 4$ & $238 \mathrm{gs}$ & Coreidae & Hypselonoltus fulvus & +++ & $\mathrm{P}$ & + & + \\
\hline $\mathrm{J} 5$ & $238 t d$ & Coreidae & Hypselonoltus fulvus & +++ & $\mathrm{P}$ & + & + \\
\hline M3 & $189 t d$ & Coreidae & Hypselonoltus fulvus & + & $\mathrm{P}$ & + & + \\
\hline N4 & $195 t d$ & $\mathrm{NI}$ & $\mathrm{NI}$ & + & $\mathrm{P}$ & + & + \\
\hline N5 & 207gs & $\mathrm{NI}$ & $\mathrm{NI}$ & + & $\mathrm{P}$ & + & + \\
\hline N6 & $207 \mathrm{td}$ & $\mathrm{NI}$ & $\mathrm{NI}$ & + & $P$ & + & + \\
\hline $\mathrm{O} 2$ & $213 t d$ & $\mathrm{NI}$ & $\mathrm{NI}$ & + & $\mathrm{P}$ & + & + \\
\hline P6 & $168 \mathrm{gs}$ & Coreidae & L flavovittata & + & $P$ & + & + \\
\hline Q1 & $168 \mathrm{td}$ & Coreidae & $L$ flavovittata & + & $P$ & + & + \\
\hline Q2 & 169tdg & Coreidae & L flavovittata & + & $\mathrm{P}$ & + & + \\
\hline $\mathrm{R} 2$ & $294 \mathrm{td}$ & Coreidae & Veneza sp & + & $P$ & + & + \\
\hline R3 & $296 \mathrm{td}$ & Reduvidae & Arilus carinatus & + & PC & + & + \\
\hline R4 & $297 \mathrm{td}$ & Coreidae & Veneza stigma & + & $\mathrm{P}$ & + & + \\
\hline $\mathrm{S} 2$ & $300 t d$ & Coreidae & Veneza sp & + & $\mathrm{P}$ & + & + \\
\hline S6 & $129 t d$ & Lygaeidae & $\mathrm{NI}$ & ++ & $P$ & + & + \\
\hline $\mathrm{T} 1$ & $129 \mathrm{gs}$ & Lygaeidae & NI & +++ & $P$ & + & + \\
\hline T3 & $134 \mathrm{td}$ & Lygaeidae & $N I$ & +++ & $P$ & + & + \\
\hline U5 & 121gs & Coreidae & Crinocerus sanctus & + & $\mathrm{P}$ & + & + \\
\hline $\mathrm{Z1}$ & 83td & Coreidae & Hypselonoltus fulvus & + & $P$ & + & + \\
\hline $\mathrm{Z} 2$ & $82 \mathrm{td}$ & Coreidae & Hypselonoltus fulvus & + & $\mathrm{P}$ & + & + \\
\hline 25 & 265 td & Coreidae & Veneza sp & + & $P$ & + & + \\
\hline 26 & $267 \mathrm{td}$ & Coreidae & Veneza sp & + & $\mathrm{P}$ & + & + \\
\hline 31 & 268gs & Coreidae & Veneza stigma & + & $\mathrm{P}$ & + & + \\
\hline 34 & $245 \mathrm{gs}$ & Coreidae & Hypselonoltus fulvus & + & $\mathrm{P}$ & + & + \\
\hline 35 & $245 \mathrm{td}$ & Coreidae & Hypselonoltus fulvus & + & $\mathrm{P}$ & + & + \\
\hline
\end{tabular}

MI, investigação microscópica; F,morfologia; Try-SLPCR,PCR especifico para tripanossomatídeos, SL3', sonda 
Tabela 14 Detecção de Phytomonas usando como molde o DNA de glândulas salivares e tubo digestivo por amplificação por Try-SLPCR e hibridação com SL3' tripanossomatídeos extraídos de lâminas, negativos para MI.

\begin{tabular}{cccccccc}
\hline Cód. & Isol. & Família & \multicolumn{1}{c}{ Espécie } & MI & F & $\begin{array}{c}\text { Try-SL } \\
\text { PCR }\end{array}$ & SL' \\
\hline D2 & 243gs & Coreidae & Hypselonoltus fulvus & - & - & + & + \\
E1 & 270gs & Coreidae & Veneza stigma & - & - & + & + \\
\hline
\end{tabular}

MI, investigação microscópica; F,morfologia; Try-SLPCR,PCR especifico para tripanossomatídeos, SL3', sonda

Tabela 15 Amplificação por Try-SLPCR e hibridação com SL3' do DNA de tripanossomatídeos extraídos de lâminas

\begin{tabular}{|c|c|c|c|c|c|c|c|}
\hline Cód. & Isol. & Família & Espécie & MI & $\mathrm{F}$ & $\begin{array}{c}\text { Try-SL } \\
\text { PCR }\end{array}$ & SL3' \\
\hline B4 & $287 t d$ & Coreidae & Veneza sp & ++ & $P$ & + & - \\
\hline $\mathrm{C} 2$ & $290 t d g$ & Coreidae & Veneza sp & + & $P$ & + & - \\
\hline D5 & $268 t d$ & Coreidae & Veneza stigma & + & $P$ & + & - \\
\hline E2 & $270 t d$ & Coreidae & Veneza stigma & + & $P$ & + & - \\
\hline E6 & $273 g s$ & Coreidae & Phthia Iunata & + & $P$ & + & - \\
\hline $\mathrm{F} 1$ & $273 t d$ & Coreidae & Phthia Iunata & + & $P$ & + & - \\
\hline $\mathrm{H} 4$ & 198td & Coreidae & Hypselonoltus fulvus & + & $P$ & + & - \\
\hline 15 & 233td & Coreidae & Hypselonoltus fulvus & +++ & $\mathrm{P}$ & + & - \\
\hline 16 & $234 t d$ & Coreidae & Hypselonoltus fulvus & +++ & $P$ & + & - \\
\hline J6 & 239gs & Coreidae & Hypselonoltus fulvus & +++ & $\mathrm{P}$ & + & - \\
\hline L1 & $205 t d$ & $\mathrm{NI}$ & $\mathrm{NI}$ & + & $P$ & + & - \\
\hline L2 & 206td & $\mathrm{NI}$ & $\mathrm{NI}$ & + & $P$ & + & - \\
\hline L6 & 176td & Lygaidae & $\mathrm{NI}$ & + & $\mathrm{P}$ & + & - \\
\hline M1 & 180td & Coreidae & Hypselonoltus fulvus & + & $P$ & + & - \\
\hline M2 & $182 \mathrm{td}$ & NI & $\mathrm{NI}$ & + & $P$ & + & - \\
\hline M4 & 190gs & Coreidae & Hypselonoltus fulvus & + & $P$ & + & - \\
\hline M5 & 190td & Coreidae & Hypselonoltus fulvus & + & $\mathrm{P}$ & + & - \\
\hline M6 & 192gst & Coreidae & Phthia picta & + & $P$ & + & - \\
\hline N2 & 194 td & Coreidae & Acantocephala latipes & + & $\mathrm{P}$ & + & - \\
\hline N3 & $195 t d$ & $\mathrm{NI}$ & $\mathrm{NI}$ & + & $P$ & + & - \\
\hline 01 & $212 t d$ & $\mathrm{NI}$ & $\mathrm{NI}$ & + & $\mathrm{P}$ & + & - \\
\hline $\mathrm{O} 3$ & 216td & $\mathrm{NI}$ & $\mathrm{NI}$ & + & $\mathrm{P}$ & + & - \\
\hline $\mathrm{O} 4$ & 204gs & $\mathrm{NI}$ & $\mathrm{NI}$ & + & $\mathrm{P}$ & + & - \\
\hline 05 & $112 \mathrm{td}$ & $\mathrm{NI}$ & $\mathrm{NI}$ & + & $\mathrm{P}$ & + & - \\
\hline $\mathrm{T} 2$ & $132 \mathrm{td}$ & Lygaeidae & $\mathrm{NI}$ & ++ & $\mathrm{P}$ & + & - \\
\hline T4 & 136td & Lygaeidae & $\mathrm{NI}$ & ++ & $\mathrm{P}$ & + & - \\
\hline U2 & 148td & Lygaeidae & $\mathrm{NI}$ & +++ & $\mathrm{P}$ & + & - \\
\hline U3 & 149td & Coreidae & Crinocerus sanctus & +++ & $P$ & + & - \\
\hline V6 & $112 \mathrm{td}$ & Coreidae & Veneza stigma & ++ & $\mathrm{P}$ & + & - \\
\hline $\mathrm{X} 1$ & $107 \mathrm{td}$ & Coreidae & Crinocerus sanctus & + & $\mathrm{P}$ & + & - \\
\hline$X 4$ & 103gs & Coreidae & Crinocerus sanctus & ++ & $\mathrm{P}$ & + & - \\
\hline$\times 5$ & $101 \mathrm{td}$ & Coreidae & Crinocerus sanctus & + & $\mathrm{P}$ & + & - \\
\hline$X 6$ & $167 t d$ & Coreidae & Crinocerus sanctus & + & $P$ & + & - \\
\hline
\end{tabular}




\begin{tabular}{llllllll}
\hline Y1 & $100 t d$ & Coreidae & Crinocerus sanctus & + & $\mathrm{P}$ & + & - \\
Y2 & $99 \mathrm{gs}$ & Coreidae & Crinocerus sanctus & + & $\mathrm{P}$ & + & - \\
Y3 & $93 \mathrm{td}$ & Coreidae & Hypselonoltus fulvus & + & $\mathrm{P}$ & + & - \\
Y4 & $91 \mathrm{gs}$ & Coreidae & Hypselonoltus fulvus & + & $\mathrm{P}$ & + & - \\
Y5 & $90 \mathrm{td}$ & Largidae & Largus humilis & ++ & $\mathrm{P}$ & + & - \\
W1 & $88 \mathrm{td}$ & Coreidae & Hypselonoltus fulvus & + & $\mathrm{P}$ & + & - \\
W2 & $87 \mathrm{td}$ & Coreidae & Hypselonoltus fulvus & + & $\mathrm{P}$ & + & - \\
Z3 & $81 \mathrm{td}$ & Coreidae & Hypselonoltus fulvus & + & $\mathrm{P}$ & + & - \\
15 & $13 \mathrm{td}$ & Largidae & Largus humilis & + & $\mathrm{P}$ & + & - \\
22 & $260 \mathrm{td}$ & NI & Nl & + & $\mathrm{P}$ & + & - \\
23 & $261 \mathrm{td}$ & coreidae & Phthia lunata & + & $\mathrm{P}$ & + & - \\
24 & $263 \mathrm{td}$ & Coreidae & Sphictyrtus cryseis & + & $\mathrm{P}$ & + & - \\
32 & $239 \mathrm{gs}$ & Coreidae & Hypselonoltus fulvus & +++ & $\mathrm{P}$ & + & - \\
33 & $242 \mathrm{gs}$ & Coreidae & Hypselonoltus fulvus & + & $\mathrm{P}$ & + & - \\
36 & $246 \mathrm{gs}$ & Coreidae & Veneza stigma & + & $\mathrm{P}$ & + & - \\
51 & $232 \mathrm{td}$ & Coreidae & Hypselonoltus fulvus & +++ & $\mathrm{P}$ & + & - \\
53 & $122 \mathrm{td}$ & Coreidae & Crinocerus sanctus & +++ & $\mathrm{P}$ & + & - \\
55 & $126 \mathrm{td}$ & Coreidae & Crinocerus sanctus & +++ & $\mathrm{P}$ & + & - \\
56 & $127 \mathrm{td}$ & Coreidae & Hypselonoltus fulvus & ++ & $\mathrm{P}$ & + & - \\
\hline
\end{tabular}

MI, investigação microscópica; F,morfologia; Try-SLPCR,PCR especifico para tripanossomatídeos, SL3', sonda

Tabela 16 Amplificação por Try-SLPCR e hibridação com SL3' de DNA de tripanossomatídeos extraídos de lâminas das formas coanomastigota e amastigota.

\begin{tabular}{cccccccc}
\hline Cód. & Isol. & Família & Espécie & MI & F & $\begin{array}{c}\text { Try-SL } \\
\text { SLC }\end{array}$ & \\
\hline O6 & 153td & Lygaeidae NI & & + & C & + & - \\
P1 & 152td & Lygaeidae NI & & + & C & + & - \\
P2 & 148gs & Lygaeidae NI & & + & A & + & - \\
U4 & 152td & Lygaeidae NI & & ++ & C & + & - \\
\hline
\end{tabular}

MI, investigação microscópica; F,morfologia; Try-SLPCR,PCR especifico para tripanossomatídeos, SL3', sonda

Tabela 17 Amplificação por Try-SLPCR e hibridação com SL3' de DNA de tripanossomatídeos extraídos de lâminas, positivos para MI.

\begin{tabular}{cccccccc}
\hline Cód. & Isol. & Família & \multicolumn{1}{c}{ Espécie } & Ml & F & $\begin{array}{c}\text { Try-SL } \\
\text { PCR }\end{array}$ & SL3' \\
\hline A6 & 283td & Coreidae & Veneza sp & ++ & P & - & - \\
B1 & 284gs & Coreidae & Veneza sp & ++ & P & - & - \\
C4 & 291td & Coreidae & Veneza sp & ++ & P & - & - \\
C6 & 302td & Coreidae & Veneza sp & +++ & P & - & - \\
F3 & 274td & Coreidae & Phthia lunata & + & P & - & - \\
F5 & 275td & Coreidae & Phthia lunata & + & P & - & - \\
\hline
\end{tabular}




\begin{tabular}{|c|c|c|c|c|c|c|c|}
\hline G1 & $276 \mathrm{td}$ & Coreidae & Veneza stigma & + & $P$ & - & - \\
\hline G5 & $278 t d$ & Coreidae & Veneza stigma & + & $P$ & - & - \\
\hline $\mathrm{H} 2$ & $280 t d$ & Coreidae & Veneza stigma & +++ & $P$ & - & - \\
\hline $\mathrm{H} 3$ & 281gs & Coreidae & Veneza sp & + & $P$ & - & - \\
\hline 12 & $231 \mathrm{td}$ & Coreidae & Hypselonoltus fulvus & + & $P$ & - & - \\
\hline 13 & 232gs & Coreidae & Hypselonoltus fulvus & ++ & $P$ & - & - \\
\hline $\mathrm{N} 1$ & $193 \mathrm{td}$ & Largidae & Largus humilis & + & $P$ & - & - \\
\hline R6 & 298td & Coreidae & Veneza stigma & + & $P$ & - & - \\
\hline S5 & $302 t d$ & Coreidae & Veneza stigma & + & $P$ & - & - \\
\hline T5 & $139 t d$ & Coreidae & Hypselonoltus fulvus & ++ & $P$ & - & - \\
\hline T6 & $141 \mathrm{td}$ & Lygaeidae & $\mathrm{NI}$ & + & $P$ & - & - \\
\hline U1 & $148 g s$ & Lygaeidae & NI & ++ & $P$ & - & - \\
\hline U6 & 120gs & Coreidae & Crinocerus sanctus & +++ & $P$ & - & - \\
\hline V1 & $119 \mathrm{td}$ & Coreidae & Crinocerus sanctus & +++ & $P$ & - & - \\
\hline V2 & $118 t d$ & Lygaeidae & NI & + & $P$ & - & - \\
\hline V3 & $116 \mathrm{td}$ & Lygaeidae & NI & + & $P$ & - & - \\
\hline V4 & 113gs & Coreidae & Crinocerus sanctus & ++ & $P$ & - & - \\
\hline V5 & $112 \mathrm{gs}$ & Coreidae & Veneza stigma & + & $\mathrm{P}$ & - & - \\
\hline $\mathrm{X} 2$ & $105 \mathrm{td}$ & Largidae & Largus humilis & + & $\mathrm{P}$ & - & - \\
\hline$\times 3$ & $110 t d$ & Largidae & Largus humilis & + & $\mathrm{P}$ & - & - \\
\hline W3 & $86 \mathrm{td}$ & Coreidae & Hypselonoltus fulvus & + & $\mathrm{P}$ & - & - \\
\hline W4 & $84 \mathrm{td}$ & Coreidae & Hypselonoltus fulvus & + & $\mathrm{P}$ & - & - \\
\hline Z5 & $27 \mathrm{td}$ & Coreidae & Phthia phicta & + & $\mathrm{P}$ & - & - \\
\hline $\mathrm{Z} 6$ & $25 \mathrm{td}$ & Coreidae & Veneza stigma & + & $\mathrm{P}$ & - & - \\
\hline 11 & $25 g s$ & Coreidae & Veneza stigma & + & $\mathrm{P}$ & - & - \\
\hline 12 & $23 \mathrm{td}$ & Coreidae & Hypselonoltus fulvus & + & $\mathrm{P}$ & - & - \\
\hline 13 & $18 \mathrm{td}$ & Largidae & Largus humilis & + & $\mathrm{P}$ & - & - \\
\hline 14 & $15 \mathrm{td}$ & Largidae & Largus humilis & + & $\mathrm{P}$ & - & - \\
\hline 16 & $247 g s$ & Coreidae & Veneza stigma & + & $\mathrm{P}$ & - & - \\
\hline 21 & $247 \mathrm{td}$ & Coreidae & Veneza stigma & + & $P$ & - & - \\
\hline 41 & $246 \mathrm{td}$ & Coreidae & Veneza stigma & + & $\mathrm{P}$ & - & - \\
\hline 52 & 122gs & Coreidae & Crinocerus sanctus & + & $\mathrm{P}$ & - & - \\
\hline Z4 & $66 \mathrm{td}$ & Coreidae & Hypselonoltus fulvus & + & C & - & - \\
\hline
\end{tabular}

MI, investigação microscópica; F,morfologia; Try-SLPCR,PCR especifico para tripanossomatídeos, SL3', sonda

Tabela 18 Amplificação por Try-SLPCR e hibridação com SL3' de DNA de tripanossomatídeos extraídos de lâminas.

\begin{tabular}{cccccccc}
\hline Cód. & Isol. & Família & Espécie & Ml & F & $\begin{array}{c}\text { Try-SL } \\
\text { PCR }\end{array}$ & SL3' \\
\hline L3 & 171gs & Coreidae & Acantocephala latipes & - & - & + & - \\
42 & 254 td & Coreidae & Hypselonoltus fulvus & - & - & + & - \\
\hline
\end{tabular}

MI, investigação microscópica; F,morfologia; Try-SLPCR,PCR especifico para tripanossomatídeos, SL3', sonda

$\mathrm{O}$ isolado B6/288td, $\mathrm{Ml} \mathrm{++}$, apresentando formas promastigota e coanomastigota, amplificação Try-SLPCR - , SL3'+. 


\subsection{1 - Comparação do grupo dos Phytomonas com os grupos 1, 2, 3 e 4}

A tabela 19 registra os flagelados do gênero Phytomonas com as espécies hospedeiras, o código de identificação e as forma evolutivas. Como se pode observar, Phytomonas distribuem-se pelos 4 grupos definidos pela análise morfométrica, tabela 20. Todavia, um reparo deve ser feito. É que embora não se tenha dúvida quanto à presença de Phytomonas em uma lâmina SL3' positiva, não se pode ter certeza que os flagelados medidos sejam realmente deste gênero. Isto porque nada impede que as lâminas alberguem flagelados de mais de um gênero. Mas, de qualquer forma, a enorme dispersão morfométrica entre os flagelados examinados vem mais uma vez mostrar a precariedade da morfometria como parâmetro identificatório.

Tabela 19 - Distribuição de Phytomonas pelos diferentes grupos morfométricos.

\begin{tabular}{llccc}
\hline \multicolumn{1}{c}{ Espécie } & Código & Forma & Grupo & SL3' \\
\hline Crinocerus sanctus & 282td & $\mathrm{P}$ & 1 & + \\
Hypselonltus fulvus & 83td & $\mathrm{P}$ & 1 & + \\
Veneza $s p$ & $287 \mathrm{td}$ & $\mathrm{P}$ & 1 & + \\
Veneza $s p$ & $294 \mathrm{td}$ & $\mathrm{P}$ & 1 & + \\
Hypselonltus fulvus & $243 \mathrm{td}$ & $\mathrm{P}$ & 1 & + \\
Hypselonltus fulvus & $238 \mathrm{td}$ & $\mathrm{P}$ & 2 & + \\
Veneza $s p$ & $281 \mathrm{td}$ & $\mathrm{P}$ & 2 & + \\
Veneza $s p$ & $267 \mathrm{gs}$ & $\mathrm{P}$ & 2 & + \\
Veneza $s p$ & $287 \mathrm{gs}$ & $\mathrm{P}$ & 2 & + \\
Hypselonoltus fulvus & $244 \mathrm{gs}$ & $\mathrm{PA}$ & 3 & + \\
Hypselonoltus fulvus & $245 \mathrm{gs}$ & $\mathrm{PA}$ & 3 & + \\
Veneza stigma & $247 \mathrm{gs}$ & $\mathrm{PA}$ & 3 & + \\
Crinocerus sanctus & $148 \mathrm{gs}$ & $\mathrm{PA}$ & 3 & + \\
Hypselonoltus fulvus & $243 \mathrm{gs}$ & $\mathrm{PA}$ & 3 & + \\
Veneza $s p$ & $288 \mathrm{td}$ & $\mathrm{PC}$ & 4 & + \\
\hline P. & & & & +
\end{tabular}

$\mathrm{P}$, promastigota; $\mathrm{A}$, amastigota; $\mathrm{C}$, coanomastigota.

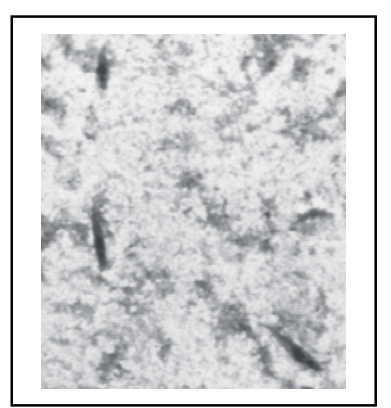

245gs Hypselonoltus fulvus

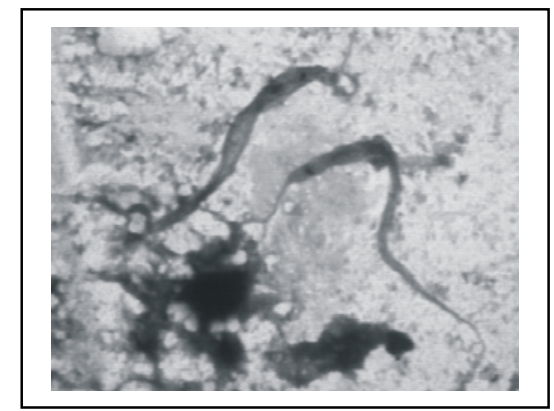

245gs Hypselonoltus fulvus 


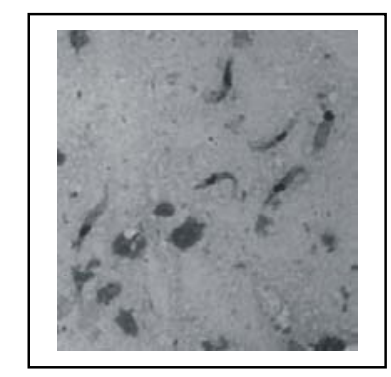

288td Veneza sp

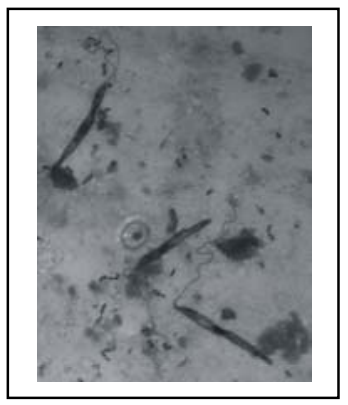

288gs Veneza sp

Tabela 20 - Medidas $\mu \mathrm{m}$ de Phytomonas spp.

\begin{tabular}{|c|c|c|c|}
\hline Isolado & C.C & c.f & c.a \\
\hline $282 \mathrm{td}$ & $12,{ }^{a} \pm 3,3^{b}(5,6-19,2)^{c}$ & $14,4 \pm 4,1(6,9-23,1)$ & $3,3 \pm 0,7(2,1-4,7)$ \\
\hline 83td & $14,0 \pm 3,8(10,1-25,3)$ & $13,4 \pm 3,1(5,2-17.0)$ & $3,4 \pm 0,9(1,9-5,5)$ \\
\hline $287 \mathrm{td}$ & $20,2 \pm 4,0(12,2-29,6)$ & $29,5 \pm 6,9(14,6-44,6)$ & $6,5 \pm 2,02,5-11,6)$ \\
\hline $294 \mathrm{td}$ & $24,1 \pm 9,2(13,9-43,1)$ & $8,7 \pm 3,0(5,0-13,1)$ & $5,6 \pm 2,0(3,0-9,5)$ \\
\hline 238td & $18,6 \pm 4,9(7,9-31,9)$ & $15,1 \pm 4,7(8,4-28,4$ & $4,2 \pm 1,1(2,0-6,7)$ \\
\hline 243td & $25,6 \pm 5,3(13,4-37,9)$ & $26,8 \pm 1,2(6,0-36,0)$ & $5,2 \pm 1,8(2,2-9.3)$ \\
\hline $281 \mathrm{td}$ & $20,6 \pm 3,9(13,1-31,4)$ & $34,9 \pm 6,6(19,0-45,1)$ & $6,6 \pm 2,0(2,4-10,6)$ \\
\hline $267 \mathrm{gs}$ & $22,4 \pm 4,1(16,4$ & $30,7 \pm 6,9(16$ & $6,6 \pm 1,9(4,1-11,1)$ \\
\hline $287 \mathrm{gs}$ & $\begin{array}{r}24,2 \pm 6,8(13,0-40,1) \\
8,8 \pm 1,5(7,1-9,8)\end{array}$ & $5,6 \pm 1,3$ & $4,1 \pm 0,83,0-6,0)$ \\
\hline 244gs & $\begin{array}{r}25,0 \pm 6,1(10,5-35,2) \\
8,8 \pm 0,7(7,1-9,9)\end{array}$ & $7,4 \pm 1,8(3,3-11,7)$ & $3,5 \pm 0,8(2,1-5,4)$ \\
\hline $245 \mathrm{gs}$ & $\begin{array}{r}25,4 \pm 6,4(12,9-37,2) \\
8,5 \pm 1,6 \quad(6,2-13,0)\end{array}$ & $11,0 \pm 2,9(7,1-15,8)$ & $3,6 \pm 0,7(2,1-5,2)$ \\
\hline 247gs & $\begin{array}{r}21,2 \pm 6,7(10,7-33,8) \\
8,8 \pm 1,2(6,7-10,9)\end{array}$ & $6,4 \pm 2,1(5,0-11,9)$ & $3,4 \pm 0,6(2,4-4,6)$ \\
\hline $148 \mathrm{gs}$ & $13,6 \pm 1,1(11,5$ & & \\
\hline $243 \mathrm{gs}$ & $\begin{array}{r}22,9 \pm 5,4(13,1-33,3) \\
8,4 \pm 1,3(6,3-11,6)\end{array}$ & $7,5 \pm 1,4(4$ & $3,3 \pm 0,8(1,9-5,5)$ \\
\hline 288td & $7,5 \pm 1,4(4,5-12,0)$ & $3,7 \pm 1,7(1,3-10,0)$ & $2,4 \pm 0,6(1,4-4,0)$ \\
\hline
\end{tabular}

\subsubsection{Análise dos resultados utilizando marcadores moleculares}

A análise dos resultados utilizando o método de Try-SLPCR e hibridação para pesquisa de tripanossomatídeos e Phytomonas ssp está compilado na tabela 21. 
Tabela 21 Relação de Trypanosomatidae e Phytomonas definidos por marcadores moleculares e espécies de hemípteros.

\begin{tabular}{|c|c|c|c|c|}
\hline & Hospedeiro de origem & & Try-SLPCR + & SL3'+ \\
\hline \multirow{2}{*}{ Família } & Espécie & $E$ & Tripanosomatideos & Phytomonas \\
\hline & Crinocerus sanctus & 33 & 6 & 3 \\
\hline & Hypselonoltus fulvus & 74 & 25 & 9 \\
\hline \multirow[t]{7}{*}{ Coreidae } & Veneza stigma & 16 & 8 & 4 \\
\hline & Veneza sp & 24 & 8 & 7 \\
\hline & Sphictyrtus cryseis & 01 & 1 & 0 \\
\hline & Lucullia flavovittata stal & 02 & 2 & 2 \\
\hline & Phthia picta & 08 & 2 & 2 \\
\hline & Phthia lunata & 05 & 4 & 2 \\
\hline & Acantocephala latipes & 02 & 1 & 0 \\
\hline Largidae & Largus humilis & 11 & 2 & 2 \\
\hline Lygaeidae & $\mathrm{NI}$ & 39 & 8 & 2 \\
\hline Miridae & ni & 11 & - & - \\
\hline Rhopalidae & Niesthrea $s p$ & 2 & - & - \\
\hline \multirow[t]{2}{*}{ Pentatomidae } & Edessa rufomarginata & 6 & - & \\
\hline & Euchistus $s p$ & 7 & - & \\
\hline \multirow[t]{2}{*}{ Reduvidae } & Arilus carinatus & 1 & 1 & 1 \\
\hline & Apromerus sp & 2 & - & \\
\hline
\end{tabular}

Try-SLPCR,PCR especifico para tripanossomatídeos, SL3', sonda especifica para Phytomonas

Dos 244 hemípteros fitófagos examinados, $13,5 \%$ foram encontrados positivos para o gênero Phytomonas. Dos 108 insetos positivos por investigação microscópica, 30,5\% foram do gênero Phytomonas. Destes insetos positivos, os órgãos infectados foram: glândulas salivares, 18\%, tubo digestivo $45 \%$ tubo digestivo e glândulas salivares, $18 \%$.

Foram 06 as espécies descritas pela primeira vez albergando Phytomonas: Crinocerus sanctus, Phthia lunata, Veneza stigma, Lucullia flavovittata stal, todas da família Coreidae, Largus humilis da família Largidae. Também foi descrito pela primeira vez como hospedeiro do gênero Phytomonas o inseto predador da família Reduvidae, Arilus carinatus. 
4. Discussão 
Tripanossomatídeos monoxênicos são encontrados com relativa freqüência em insetos hemípteros fitófagos. Tripanossomatídeos heteroxênicos do gênero Phytomonas, são encontrados em plantas, particularmente em laticíferas, e também encontrados em frutos e em plantas cultivadas como café, dendê, coqueiros e mandioca onde causam doenças de considerável importância econômica (Camargo, 1990). Admite-se de acordo com algumas evidências que estes flagelados sejam transmitidos por hemípteros fitófagos (Kastelein, 1985; Camargo, 1999), uma vez que esses flagelados são freqüentemente encontrados nas glândulas salivares desses insetos podendo ser inoculados com saliva antes ou durante a alimentação na planta hospedeira (Camargo \& Wallace, 1994). Dados da literatura mostram que dos hemípteros encontrados parasitados por flagelados, $9 \%$ eram da família Lygaeidae, $44 \%$ da família Coreidae, $40 \%$ da família Pyrrhocoridae, $18 \%$ da família Pentatomidae. Sendo a prevalência de flagelados em insetos de 35\% (Sbravate et al., 1989).

Para se ter uma avaliação da incidência de tripanossomatídeos de insetos e plantas no estado de Rondônia foi necessário um levantamento preliminar das principais espécies de insetos fitófagos na região. Dos 244 insetos encontrados $67,6 \%$ foram da família Coreidae, $5,2 \%$ da família Pentatomidae, $16 \%$ da família Lygaeidae, $4,5 \%$ da família Largidae, $4,5 \%$ da família Miridae, $1 \%$ da família Rhopalidae, todos hemípteros fitófagos e $1,2 \%$ da família Reduvidae, inseto predador (dados na tabela 1 e 2).

Em seus estudos Sbravate et al., (1989) encontraram uma prevalência de $35 \%$ de flagelados em hemípteros fitófagos. Em nosso estudo, por investigação microscópica, dados da tabela 2 , foi mostrada a prevalência de flagelados em fitófagos é mais elevada, da ordem de $44 \%$. Insetos de 5 famílias de Hemíptera foram encontradas parasitadas por tripanossomatídeos, sendo 4 famílias de fitófagos. Entre estas, na família. Coreidae, dos 165 examinados, $54 \%$ se encontraram parasitados por flagelados; na família. Pentatomidae, do total de 13 examinados, $7 \%$ abrigavam parasitas flagelados; na família Lygaeidae, dos 39 examinados $20 \%$ foram positivos; na família. Largidae foram examinados 11 
insetos e $72 \%$ estavam abrigando flagelados. Mesmo já tendo sido descrita como albergando tripanossomatídeos, a família Miridae (Camargo \& Wallace, 1994) não apresentou insetos infectados assim como a família Rhopalidae. Também foram encontrados $33 \%$ de insetos parasitados na família Reduvidae. Os Coreidae $(54 \%)$ e Largidae $(72 \%)$, foram os mais freqüentemente encontrados positivos para flagelados. Embora nossas coletas dessem preferência aos insetos colonizadores da floresta, muitos foram coletados em plantas cultivadas onde sabidamente prevalecem os Coreidae.

Entre os hemípteros fitófagos examinados por investigação microscópica dados da tabela 3 comparados com Camargo \& Wallace (1994), uma família Largidae, três gêneros, Crinocerus, Lucullia e Acantocephala e duas espécies, Phthia lunata e Veneza stigma, foram pela primeira vez descritas como hospedeiros de flagelados.

Os resultados de nossas coletas mostraram não haver diferenças de infecção por tripanossomatídeos tanto no inverno (44\%) quanto no verão $(44 \%)$ (tabela 2). As porcentagens de insetos infectados nas duas estações climáticas foram, portanto, bastante aproximadas o que parece sugerir que as infecções estejam presentes o ano todo, o que contrasta com regiões temperadas e frias onde as taxas de infecção são menores no inverno.

Antes da análise que se segue, algumas observações se fazem necessárias a respeito da metodologia utilizada. Apesar de invalidada como parâmetro de identificação da família Trypanosomatidae (Camargo, 1999) procedeu-se a análise morfológica e morfométrica dos flagelados para organizar grupos que pudessem ser comparados com os resultados das provas moleculares, uma vez que é a primeira vez que estuda-se Phytomonas e outros tripanossomatídeos na região do estado de Rondônia

Os tripanossomatídeos referidos na literatura como parasitas de hemípteros fitófagos pertencem aos gêneros Leptomonas, Phytomonas, Crithidia, Blastocrithidia e Herpetomonas. Ao examinarmos os esfregaços corados com 
Giemsa do conteúdo intestinal e glândulas salivares de insetos, encontramos 88\% de formas promastigotas, $4 \%$ de coanomastigotas e $8 \%$ de amastigotas, estes sempre associadas com formas promastigotas. Excetuando-se os coanomastigotas típicos do gênero Crithidia, formas promastigotas são comuns à maioria dos gêneros de tripanossomatídeos inferiores. Outra característica comum da análise morfológica diz respeito ao intenso polimorfismo que Jankevicius et al., (1989) já haviam descrito em flagelados de um mesmo inseto vetor. Entre promastigotas existe um polimorfismo muito acentuado tanto em relação a comprimento do corpo quanto ao do flagelo. Além disso, alguns promastigotas apresentam uma ou mais torções ao longo do corpo ausente na maioria. Obedecendo a um critério puramente morfométrico os tripanossomatídeos foram organizados em 4 grupos conforme as dimensões do flagelo livre e do corpo, a presença ou ausência de torções ao longo do corpo, e a presença concomitante de formas amastigotas (tabelas 5, 6, 7, 8, 9, 10, 11 e 12). Essa análise morfométrica dos parasitas, embora tenha nos permitido distribuí-los em 4 grupos, não serviu para distinguir os gêneros dos parasitas e, portanto identificar o gênero Phytomonas entre eles.

A dificuldade do cultivo in vitro dos tripanossomatídeos do gênero Phytomonas prejudica a correta identificação e os dados reais da prevalência destes flagelados em insetos e plantas (Teixeira, et al., 2000). Em virtude destas dificuldades, dos 108 hemípteros fitófagos encontrados parasitados por tripanossomatídeos, somente $4 \%$ foram isolados para futuras culturas e testes, ou seja, uma pequena amostra em relação ao número de insetos parasitados (tabela 4).

Em virtude das dificuldades de isolamento e cultura, para obtermos dados sobre a real prevalência de Phytomonas em insetos fitófagos, utilizamos técnicas de diagnóstico molecular recentemente desenvolvidas.

A adaptação e o uso do método SL-PCR seguido de hibridação (Southern blot) com sonda para esfregaços em lâminas, veio resolver vários problemas na pesquisa de Phytomonas e/ou outros tripanossomatídeos em regiões onde as 
facilidades laboratoriais são precárias ou nem existem, pois este método não requer o isolamento e o cultivo de flagelados (Teixeira et al., 2000). Utilizando o SL-PCR, à temperatura de $48^{\circ} \mathrm{C}$ (Serrano et al., 1999a) seguida de hibridação com a sonda SL3' foi possivel identificar Phytomonas entre as amostras de tripanossomatídeos. Além disso, dois isolados negativos para $\mathrm{Ml}$ foram detectados Try-SLPCR (+) e SL3'(+) (tabela 14) demonstrando a sensibilidade e as vantagens da pesquisa utilizando a amplificação por PCR. (Tabela 21).

Dos 244 hemípteros fitófagos examinados, 13,5\% foram encontrados positivos para o gênero Phytomonas. Dos 108 insetos positivos por investigação microscópica, 30,5\% foram do gênero Phytomonas. Destes insetos positivos, os órgãos infectados foram: glândulas salivares, $18 \%$, tubo digestivo $45 \%$ tubo digestivo e glândulas salivares, $18 \%$.

Estes resultados mostram claramente a utilidade do SL-PCR em levantamento epidemiológicos sobre a ocorrência de Phytomonas entre insetos, tarefa que seria praticamente impossível se dependêssemos de isolamento e cultura dos flagelados, particularmente em regiões em que esses procedimentos enfrentam inúmeras dificuldades (Teixeira et al., 2000).

Outra observação que merece ser ressaltada é a de que hemípteros também podem abrigar simultaneamente tripanossomatídeos inferiores de mais de um gênero. Esta última observação foi sempre prejudicada no passado pelo fato de que isolamento e cultura tendem a privilegiar uma espécie de flagelados entre as várias que podem ser encontradas em um inseto. Por isso, infecções múltiplas permaneceram e permanecem críticas nos métodos tradicionais de diagnóstico.

Finalmente, a utilização do método nos permitiu identificar 6 novas espécies hospedeira de Phytomonas: Crinocerus sanctus, Phthia lunata, Veneza stigma, Lucullia flavovittata, fitófagos da família Coreidae, Largus humilis da família Largidae e o predador Arilus carinatus da família Reduvidae. 
5. Conclusão 
As espécies de insetos hemípteros fitófagos encontrados na região do estado de Rondônia, durante o período da coleta, são das famílias Coreidae, Largidae, Lygaeidae, Pentatomidae, Rhopalidae e Miridae, sendo os Coreidae os mais comumente encontrados.

Os insetos são encontrados na mesma proporção durante o ano todo, sem apresentar variações sazonais.

A presença de infecção nos insetos é a mesma nas duas estações climáticas independente do hemíptero examinado.

Entre as famílias de hemípteros analisadas os Coreidae apresentam maior taxa de infecção por tripanossomatídeos.

Os tripanossomatídeos encontrados nas glândulas salivares ou tubo digestivo apresentam sempre acentuado polimorfismo.

A caracterização dos gêneros de tripanossomatídeos pelo "amplificação do "spliced leader" e hibridação com a sonda SL3' permitiu verificar que :1/3 dos tripanossomatídeos encontrados nos hemípteros fitófagos eram do gênero Phytomonas;

Os hemípteros fitófagos da família Coreidae foram os que mais apresentaram Phytomonas.

Phytomonas foram encontrados infectando o tubo digestivo, a glândula salivar e também a hemocele.

Insetos que abrigam Phytomonas também podem hospedar outros gêneros de tripanossomatídeos inferiores. 
Além disso, pudemos identificar 06 novas espécies hospedeiras de Phytomonas: Crinocerus sanctus, Phthia lunata, Veneza stigma, Lucullia flavovittata da família Coreidae, Largus humilis da família Largidae e o inseto predador Arilus carinatus da família Reduvidae. 
6. Referências Bibliográficas 
Agabian, N. (1990). Trans-splicing on nuclear pré-mRNAs. Cell 61: 1157-1160.

Aragão, H. B. (1927). Sur um flagellé du látex de Manihot palmata, Phytomonas françai n. sp. Comptes Rendus dês Séanses de la Société de Biologie 97: 1077- 1080.

Camargo, E.P. (1964). Growth and differentiation in Trypanossoma cruzi. Origin of metacyclic trypanosomes in liquid media. Revista do Instituto de Medicina Tropical de São Paulo 6: 93 -100.

Camargo, E. P., Mattei D., Barbieri, C.L., and Morel, C.M. (1982). Eletrophoreticanalysis of endonucleases - generated fragments of $k$ - DNA, of esterase isoenzymes and of surface proteins as aids for species identification of insects. Trypanosomatids. Journal of Parasitology 29: 251 258.

Camargo, E. P., Silva, S, Roitman, I., De Souza, Jankevicius, J. V., and Dollet, M. (1987). Enzymes of ornitine-arginine metabolism in trypanossomatids of the genus Phytomonas. Journal of Protozoology 34: 439 - 441.

Camargo, E. P., Kastelein,P. and Roitman, I. (1990). Trypanossomatid parasites of plants (Phytomonas). Parasitology Today 6: 22 - 25.

Camargo, E. P., Sbravate C., Teixeira, M.M.G., Uliana, S. R., Soares, M. B. M., Affonso, H.T., and Floeter-Winter, L. (1992). Ribossomal DNA restriction analysis and synthetic oligonucleotide probing in the identification of genera of lower trypanossomatids. Journal of Parasitology 78: 40 - 48.

Camargo, E. P.,and Wallace, G. (1994). Vector of plant parasites of the genus Phytomonas (Protozoa, Zoomastigophorea, kinetoplastida). In "Advances in Disease Vector Research" (K.F., Harris, Ed.), pp. 333 - 359. Springer-Verlag, New York, NY.

Camargo, E, P. (1999). Phytomonas and other parasites of plants and fruit. Advances in Parasitology, 42: $29-112$.

Campaner, M. Prevalência, isolamento e estudo morfológico de tripanossomatídeos de hemípteros fitófagos e plantas. São Paulo, (1991), (Dissertação de Mestrado-Instituto de Ciências Biomédicas de Universidade de São Paulo).

Conchon, I., Campaner, M., Sbravate, C., and Camargo, E. P.(1989). Trypanossomatids, other than Phytononas sp., isolated and cultured from fruit. Journal of Protozoology 36: 412 - 414.

Dollet, M., Cambrony, D. And Gargani, D. (1982). Culture axenique in vitro de Phytomonas sp (Trypanosomatidae) d'Euphorbe transmis par Stenocephalus 
agilis Scop (Coreide). Comptes Rendus de l'Académie de Sciences, Paris 295: $547-550$.

Fiorini, J. E., Cucolichio, G., Rezende, D., Faria e Silva P. M. Soares, M.J. and DeSouza, W. (1996). Biochemical and morphological study of o trypanossomatid isolated from mulberry [Abstract]. Memórias do Instituto Oswaldo Cruz 91: 99.

França, C., (1920). La flagellose dês euphorbes. Annales de L'Institut Pasteur, Paris 34, 432 - 465

Hoare, C. A. and Wallace, F. G.(1966). Developmental stages of trypanossomatid flagellates: a new terminology. Nature 212: 1385 -1386.

IBGE, Instituto Brasileiro de Geografia e Estatística, (1995). Censo Agropecuário do estado de Rondônia.

IBGE, Instituto Brasileiro de Geografia e Estatística, (1996). Censo Agropecuário do estado de Rondônia.

Jankevicius, J. V., Jankevicius, S. I., Campaner, M., Conchon, I., Maeda, L. A., Teixeira, M. M. G., Freymuller, E. And Camargo, E. P. (1989). Life cycle and culturing of Phytomonas serpens (Gibbs), a trypanossomatid parasite of tomatoes. Journal of Protozoology 36: 265 - 271.

Kastelein,P.; (1985). Transmission of Phytomonas sp (Tripanossomatidae) by the bug Edessa loxdali (Pentatomidae). Surinaamse Land Bolew 33, 62- 64.

Lafont,A. (1910). Sur la presence d'un Leptomonas, parasite de la classe des Flagellés, dans le latex de trois Euphorbiacées. Annales de l' Institut Pasteur, Paris 24: 205 -219.

Maniatis, T.; Fritsch, E.F.; Sambrook, J. Molecular cloning: a laboratory manual, New York, Cold Spring Harbor Laboratory (1982).

Nunes, N. R., Teixeira, M. M. G., Camargo, E. P. \& Buck, G. A. (1995). Sequence and structural characterization of the spliced leader genes and transcripts in Phytomonas. Mol. Biochem. Parasitol 74: 233 -237.

Petry, K., Shotellius, J. and Dollet, M. (1987). Differentiation of Phytomonas sp. and lower trypanossomatids (Herpetomonas, Crithidia) by agglutination tests with lectins. Parasitology Research 74: 1 - 4.

Riou, J. F., Dollet, M., Ahomadegbe, J. C., Dominique, C. and Riou, G. (1987). Caracterization of Phytomonas ssp. Kinetoplast DNA, a plant pathogenic tripanossomal species.FEBS Letters 213: 304 - 308. 
Sbravate, C., Campaner, M., Camargo, L.E.A., Conchon, I., Teixeira, M. M. G., and Camargo, E.P. (1989). Culture and generic identification of trypanossomatids of phytophgous hemíptera in Brazil. Journal of Protozoology 36: 543 - 547

Serrano, M., G., Nunes, L., R., Campaner, M., Buck, G., A., Camargo, E., P., Teixeira, M., M., G., (1999a) Trypanosomatidae: Phytomonas detection in plants and phytofagous insects by PCR amplification of genus-especific sequence of the splice leader gene. Exp. Parasitol. 91: 268 - 269.

Serrano, M., Campaner, M., Buck, G., A., Teixeira, M., M., G. \& Camargo, E. P. (1999b). PCR amplification of the spliced leader gene for the diagnosis of tripanossomatid parasites of plants and insects in methanol fixed smears. FEMS Microbiol.Letters, 176: 241- 246.

Serrano, M. G., Camargo, E. P., Teixeira, M. M. G., (1999c). Phytomonas, Analysis of Polymorphism and Genetic Relatedness between Isolates from Plants and Phytophagous Insects from Different Geographic Regions by RAPD Fingerprints and Synapomorphic Markers. Eukaryotic Microbiology 46: $617-675$

Silva, J. B. T. and Roitman, I. (1989). Growth of Phytomonas serpens in a chemically defined medium [Abstract]. Memórias do Instituto Oswaldo Cruz 84: 157.

Sturm, N., Fernandes, O. and Campbell, D. A. (1995). The mini-exon genes of three Phytomonas isolates that differ in plant tissue tropism. FEMS Microbiology Letters 130: 177-182.

Wallace, F.G., (1966). The trypanossomatids of insects and arachnids. Experimental Parasitology 18, 124 -193.

Wallace, F.G., Camargo, E.P., McGhee, R. B., and Roitman, I. (1983). Guidelines for the description of lower trypanosomatids. J. Protozool. 30: 308 - 313.

Teixeira, M. M. G. and Camargo, E. P. (1989). Monoclonal antibodies for the identification of trypanossomatids of the genus Phytomonas, Journal of Protozoology 36: 262 - 264.

Teixeira, M. M. G., Campaner, M. and Camargo, E. P. (1994). Detection of trypanossomatid Phytomonas parasitic in plants by polymerase chain reaction aplification of $18 \mathrm{~S}$ ribossomal DNA. Parasitology Research 80: 512 516.

Teixeira, M. M. G. , Campaner, M. and Camargo, E. P. (1995). Caracterization of the target-antigens of anti Phytomonas specific monoclonal antibodies. Journal of Eukaryotic Microbiology 42: 232 - 237. 
Teixeira, M. M. G., Serrano, M. G., Nunes, L. R., Campaner, M. Buck, G. and Camargo, E. P. (1996). Trypanossomatidae: a splice-leader derived probe specific for thre genus Phytomonas. Experimental Parasitology 84: 311 319.

Teixeira, M. M. G., Takata, C. S. A, Conchon, I., Campaner, M. and Camargo, E. P. (1997). Ribossomal and kDNA markers distinguish two sub-groups of Herpetomonas among old species and new trypanossomatids isolated from flies. Journal of Parasitology 83: 58 - 65.

Teixeira, M. M. G., Serrano, M. G., Camargo, E. P. (2000). New Data from Old Trypanossomatid Preparations. Parasitology Today 16: 261 - 263.

Ullu, E., Tschudi, C., and Gunzl, A. Trans splicing in trypanossomatid protozoa Molecular Biology of Parasitc Protozoa - (1996). IRL PRESS, OXFORD UNIVERSITY PRESS, Oxford, New York, Tokio. 


\section{RESUMO}

Tripanossomatídeos particularmente os do gênero Phytomonas, podem infectar, frutos, látex, seiva, floema e flores de muitas famílias de vegetais, e foram detectados em insetos fitófagos de seus possíveis vetores em várias regiões do Velho e Novo Continente.

Em contraste com a enorme variedade da flora e da fauna entomológica da Amazônia Brasileira, poucas espécies têm sido descritas albergando tripanossomatídeos.

Os tripanossomatídeos pertencentes a estes gêneros podem apresentar formas evolutivas típicas que permitem a sua identificação morfológica. No entanto as formas promastigota, existentes tanto no ciclo evolutivo dos gêneros Herpetomonas, Leptomonas e Phytomonas, não permitem a identificação morfológica, sendo necessário parâmetros adicionais para a diferenciação entre os gêneros.

A dificuldade do cultivo "in vitro", impede a correta avaliação da presença destes parasitas em insetos e plantas, impossibilitando uma avaliação do universo dos tripanossomatídeos.

No presente trabalho foram realizadas 37 coletas de hemípteros adultos, no estado de Rondônia, nas duas estações climáticas regional durante o período de 1998 a 1999. Foram coletados 244 hemípteros pertencentes a 17 espécies diferentes as quais 13 se revelaram portadoras de tripanossomatídeos.

Das amostras positivas foram feitos esfregaços em lâminas e corados com Giemsa para posterior análise morfológica e morfométrica.

Numa segunda etapa fizemos aplicação do PCR (reação em cadeia da Polimerase) em DNA recuperado de esfregaços em lâminas para pesquisa de tripanossomatídeos de insetos e plantas seguido de hibridação com sonda SL3' específica para pesquisa do gênero Phytomonas, com vistas a um estudo preliminar da presença de tripanossomatídeos e Phytomonas em Hemípteros Fitófagos no estado de Rondônia sem necessidade de isolamento e cultura axênica dos parasitas. 


\section{ABSTRACT}

Tripanossomatids, particularly Phytomonas, may infect the fruit, latex, sap, phloem and flowers of many plant families. These parasites have also been detected in phytofagous insects which are potential vectors in many areas of the Old and New World.

In spite of the enormous variety of flora and entomological fauna of the Brazilian Amazon only a few species have been described harbouring tripanossomatids.

Some genera of tripanossomatids present typical morphological forms which they can be identified. However, the promastigote form occurs in the genera Herpetomonas, Leptomonas and Phytomonas, so other parameters are needed to separate them.

The difficulties of in vitro cultivation also hinders determining the presence of these parasites in both insects and plants, thus making it impossible to estabilish realistic incidence rates of these ubiquitous parasites.

In the present study 37 collections of adult hemipterans were made in Rondônia State during the different regional seasons of 1998 to 1999. A total of 244 bugs belonging to 17 species were collected of which 13 had trypanosomatid infections.

Methanol fixed smears of all the infections were made on glass slides and stained with Giemsa for the morphological studies and morphometric analyses.

In a second phase, we used the PCR (Polimerase Chain Reaction) to recover DNA from the methanol fixed smears. The PCR products were hybridized with the SL3' probe which is specific for Phytomonas. The aim of this preliminary study was to locate trypanosomatids infections in phytophagous Hemiptera captured in Rondônia State and then determine which of these belonged to the genus Phytomonas without the necessity of isolation in culture. 